\title{
A Taxonomic Investigation into the Red Alga Plocamium within New Zealand
}

\author{
BY
}

MADELINE WYNN COOPER

A thesis submitted to Victoria University of Wellington in partial fulfillment for the requirements for the degree of Master of Science in Marine Biology

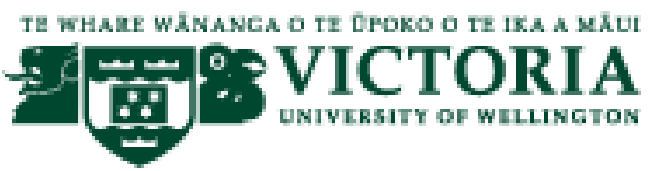

Victoria University of Wellington

2017 


\section{Abstract}

The red alga Plocamium is a cosmopolitan genus, known for its distinct branching pattern and rich chemical composition. Recent studies indicate morphological-based species delimitation approaches have failed to accurately discern diversity, distributions, and evolutionary relationship between species worldwide. Currently there are seven recognized species within New Zealand based on traditional morphological approaches and no molecular based work focused on discerning true diversity of New Zealand species in this genus. This thesis is the first to use molecular-assisted alpha taxonomy to investigate Plocamium within New Zealand. Phylogenetic analyses (Maximum Likelihood and Bayesian Inference) based on COI, $r b c \mathrm{~L}$, LSU and combined LSU/COI markers, three molecular species delimitation methods (Automatic Barcode Gap Discovery, General Mixed Yule Coalescent, and Bayesian implementation of the Poisson Tree Processes), and morphometric analyses of various characters (width of main axis (WMA), width of lowest basal ramuli (WLBR), length of lowest basal ramuli (LLBR), number of alternating series of ramuli (NASR), average number of ramuli per alternating series (ANRAS), curvature of basal ramuli (CBR) and serrations present or absent from basal ramuli (SERBR) were used to address this topic. The species delimitation methods revealed at least eleven (A-K) putative genetic species (with some incongruences) within the New Zealand specimens included in the study. Morphometric analyses indicated morphology reflects genetic diversity when multiple measures of multiple characters are used, however this is not the case when considering single characters. Phylogenetic analyses revealed possible monophyly of New Zealand candidate species C-K, and possible relationships to Australian, Chilean, and Taiwanese species. However these backbone relationships were poorly supported. The results of this study indicate that Plocamium diversity within New Zealand has been underestimated and provide the first steps in discovering the true species diversity of Plocamium within New Zealand. 


\section{Acknowledgments}

I would like to express my heartfelt thanks to my supervisor Joe Zuccarello, for the opportunities you have afforded me. Your continual support, patience, teaching, and encouragement have always kept me going. I am grateful that I have been able to learn from you not only whilst completing my undergraduate degree, but during my postgraduate learning as well.

The Joe Z lab group, Maren, Sergio, and Christian, I want to thank you all for all your patience, help and contributions to this thesis. You all helped with collections, brainstorming how to get PCRs working, helped me with file formats and computer coding, for that and more, I am grateful. I am also grateful for the encouragement and support you have all provided me.

I would also like to thank Leon Perrie and the Museum of New Zealand Te Papa Tongarewa, for my scholarship. It was a huge help for my study and life at Victoria University of Wellington. The NIWA phycology group, Roberta, Wendy, Kate and Judy, thank you for your thoughtful contributions and all your help and encouragement along the way, I am so fortunate I was able to learn from you all.

To my friends and O'hana who have helped me and supported me throughout, you know who you are and thank you. Eddie and Juanita, you have been my rocks since day one. Thank you for all you both have done. Dan you can come too. 


\section{Table of Contents}

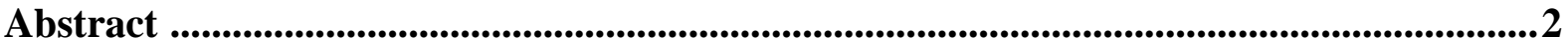

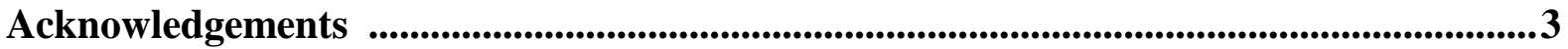

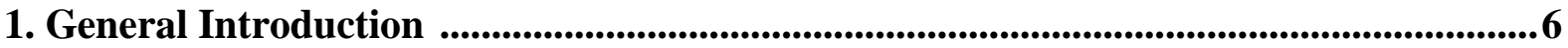

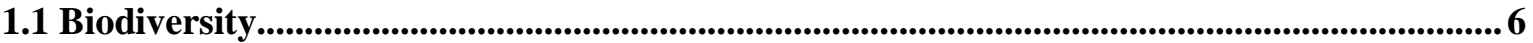

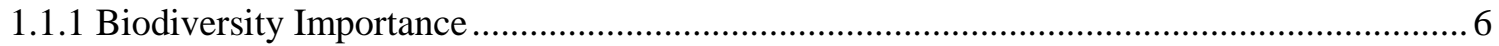

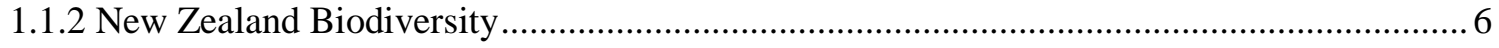

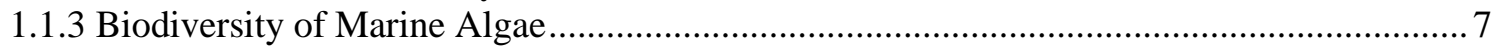

1.2 Systematics .......................................................................................................................................................... 7

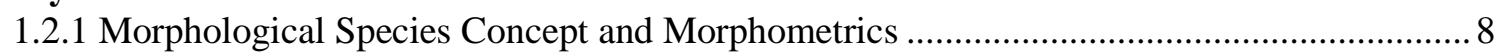

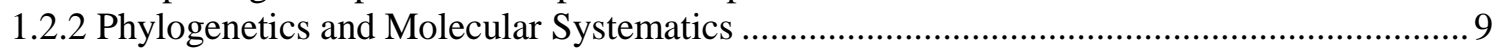

1.2.3 Integrative and Molecular-Assisted Alpha Taxonomy...................................................... 11

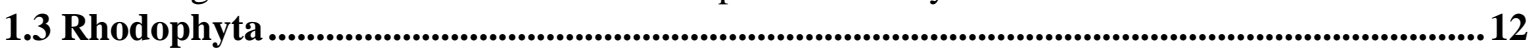

1.3.1 Red Algae: A Brief Introduction to the Biology and Life History .................................. 12

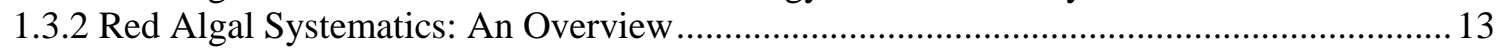

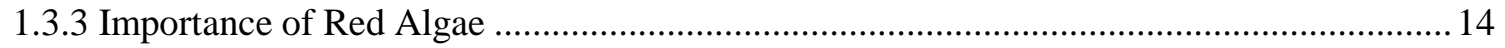

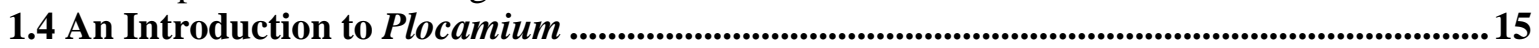

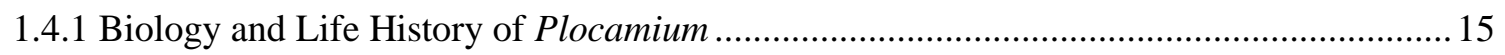

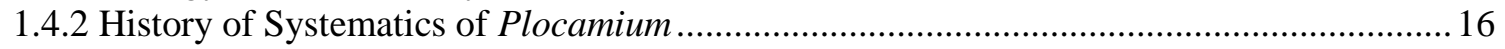

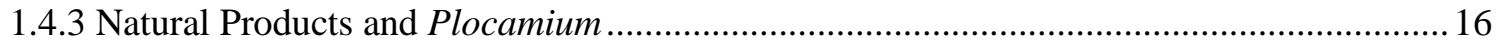

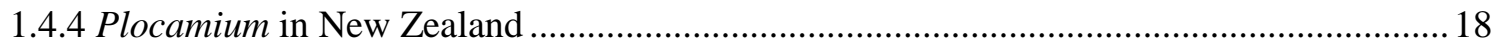

2. A Taxonomic Investigation of the Red Alga Plocamium within New Zealand ............22

2.1 Abstract n.........................................................................................................................................22

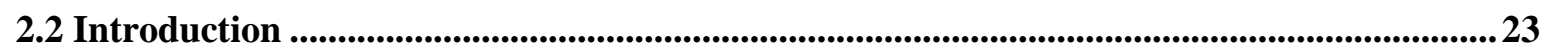

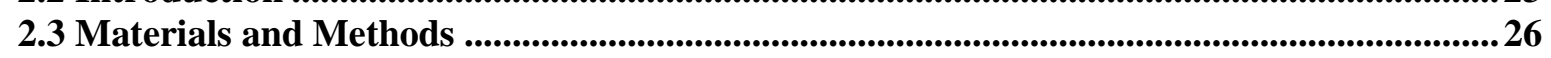

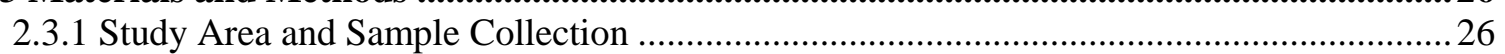

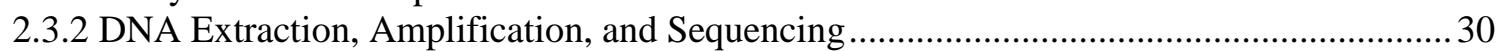

2.3.3 Multiple Sequence Alignments and Phylogenetic Analyses ........................................... 31

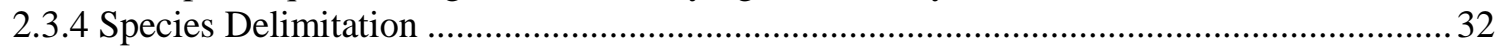

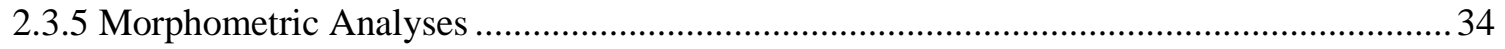

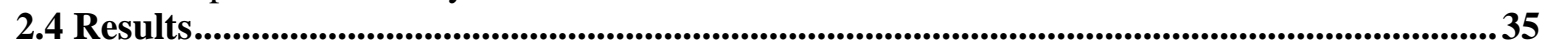

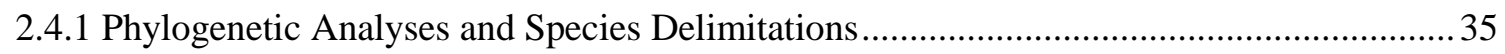

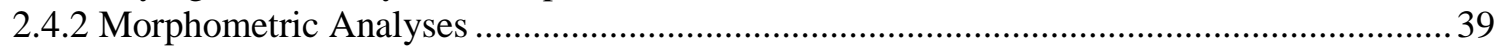

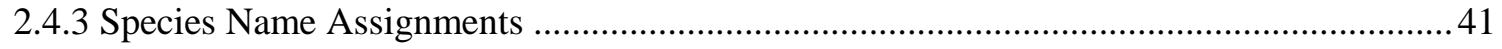

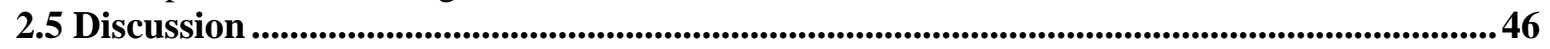

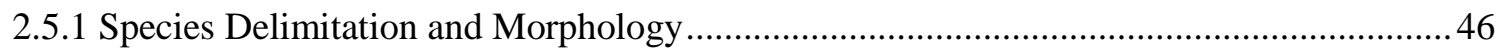

2.5.2 Application of Species Names and What More Is Needed ............................................... 48

2.5.3 New Zealand Plocamium and Its Relationship With Species in Other Parts of the World. 50

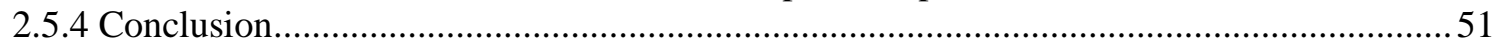

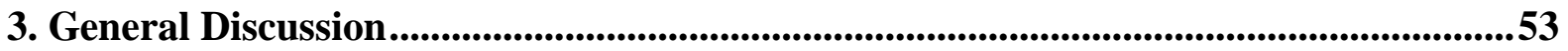

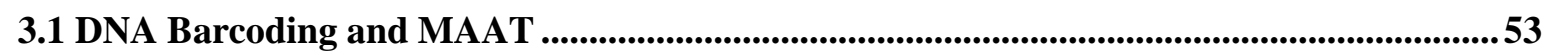

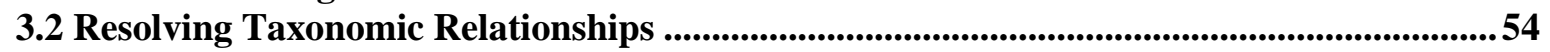

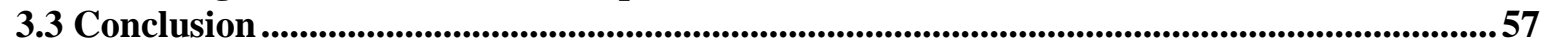

References ...................................................................................................................................................56

Supplementary Information ..................................................................................................64 
Please note that the second chapter of this thesis was written as a paper. Therefore there may be repetition found. 


\section{General Introduction:}

\subsection{Biodiversity}

\subsubsection{Biodiversity Importance}

Ecosystem functioning depends upon both abiotic and biotic factors and/or processes. Abiotic factors such as temporal and spatial environmental variation, contribute to differences in productivity, species diversity and distribution (Loreau et al. 2001, Whittaker et al. 2001). Biotic factors such as species diversity, function and interactions influence the stability of ecosystems (Tilman et al. 1994, Tilman 1996, Tilman et al. 2014, Gamfeldt et al. 2015, Lefcheck et al. 2015, Perkins et al. 2015). Recent studies indicate higher biodiversity levels are needed to sustain multi-functionality (Tilman et al. 2014, Lefcheck et al. 2015, Perkins et al. 2015). Currently the world is experiencing its sixth major extinction event (Chapin III et al. 2000) with a rapid decline of biodiversity globally (Worm et al. 2006, Schippers et al. 2015). Although it is known they are being 'lost', it is agreed that we are far from knowing what and how many species inhabit the Earth (De Clerck et al. 2013). Understanding what species are present and their taxonomy is the first step in addressing the current 'biodiversity crisis' (Schlick-Steiner et al. 2010).

\subsubsection{New Zealand Biodiversity}

New Zealand's long isolation and latitudinal range contributes to its unique terrestrial and marine biota. New Zealand has the fourth largest exclusive economic zone (EEZ) that spans across $30^{\circ}$ of latitude, including the subtropical Kermadec Islands, temperate North and South Islands, and the Subantarctic Islands (Hewitt et al. 2004, Zuccarello 2014). In the Consensus of Marine Life (2000-2010), it was established that New Zealand not only has notable terrestrial biodiversity but also high levels of species diversity within the (EEZ) marine environment (Costello et al. 2010). New Zealand has 6,500 known endemic marine 
species (Costello et al. 2010), however many species are yet to be described, with minimum estimates of around 25\% (Costello et al. 2010).

New Zealand has not been exempt from this world-wide decline in biodiversity (Rawlence et al. 2015). Considered one of the most 'conservation conscience' countries in the world (Hewitt et al. 2004), these unknown and/or undescribed species can prevent the implementation of fully effective marine reserves, inhibit biosecurity measures and impede understanding of New Zealand's biological and evolutionary history (Hewitt et al. 2004). A better understanding of these undescribed species and therefore of true species diversity is needed to make knowledgeable decisions concerning New Zealand's marine environment.

\subsubsection{Biodiversity of Marine Algae}

Marine algae are important ecologically and economically, and include both microand macro-species (Norton et al. 1996, Seckbach and Chapman 2010, Narasimharao et al. 2012). Marine macroalgae include macroscopic and multicellular members of the green (Chlorophyta), brown (Phaeophyceae), and red (Rhodophyta) algae, which were first divided based on color by Lamouroux (1813) (Saunders and Hommersand 2004, Pedersen et al. 2013). New Zealand, with 996 recognized species (Nelson et al. 2013) is considered a 'hot spot' of macroalgal diversity and endemism (Norton et al. 1996). Macroalgal diversity in New Zealand is underestimated (Nelson et al. 2013). Understanding what species are present is a first, but crucial step, before truly effective conservation strategies can be implemented, further understanding of New Zealand's evolutionary history can be had, and ecological and/or economic benefits of these organisms fully understood.

\subsection{Systematics}

Systematics is the study of biological diversity, constituting three mains elements: taxonomy, evolutionary relationships, and classification (McKelvey 1982). Alpha taxonomy 
(delimiting organisms at the species level) is fundamental to biology (Schlick-Steiner et al. 2010). Studies of biodiversity rely heavily on correct taxonomy (Phillips 2001, SchlickSteiner et al. 2010). Although many would consider systematics and taxonomy uninteresting, it is important to have correct species delimitations in order to implement effective biodiversity conservation strategies, understand evolutionary relationships between organisms, and understand biogeographic distributions of organisms (Dikow et al. 2009, Schlick-Steiner et al. 2010, Hind et al. 2014). The era of modern systematics is credited to Carl von Linné (1707 - 1778) (Manktelow 2010). Linnaeus (latinized name) was the father of the current system of taxonomy, the recognized binary nomenclature, which places organisms into various categories based on a hierarchical classification system; beginning with the most inclusive category, kingdom, trickling down into the most basic specific unit of biology, the species (Leliaert et al. 2014). Species represent the fundamental unit of biological organization (Yeates et al. 2011), however the definition and criteria used to delineate species is of great debate (Yeates et al. 2011, Leliaert et al. 2014).

\subsubsection{Morphological Species Concept and Morphometrics}

The identification of organisms based on their morphological characteristics has been a major facet in biology since the origins of scientific taxonomy (McKelvey 1982, Zinetti et al. 2013). Since Linnaeus, many researchers have named organisms that display similar morphologies and/or other visible traits together into the same species category, a classification concept known as morphological species concept (De Queiroz 2007).

In the beginning of the twentieth century, the field of taxonomy and systematics experienced a "quantitative revolution" (Bookstein et al. 1985, Adams et al. 2004). This meant the migration from non-statistic based species delimitation, towards using statistical methodology to group species based on quantitative analyses of characters and shape. The 
emerging statistical theories, such as the analysis of variance (Fisher 1935), correlation coefficient (Pearson 1895), and principal components analysis (Pearson 1901, Hotelling 1933), allowed for morphological characteristics to be analyzed statistically in species identification. Results from these stringent tests allow more weight to be given to species classification (Adams et al. 2004). These advances in statistics and the conceptualization of the need for quantitative science resulted in the modern field of morphometrics; the study and analysis of "shape variation and its covariation with other variables" (Adams et al. 2004). Morphometrics is principally used as a way to quantitatively analyze shape. It is often used for species comparison and identification, including for taxonomic purposes (Neige 2006).

The morphological species concept delineates species based on variation in morphology (Leliaert et al. 2014). Although morphological variation can be used to accurately resolve species, in many cases attempting to describe and define species based solely on their morphological character(s) has its drawbacks. Convergent morphological evolution, phenotypic plasticity, the need for reproductive tissues that are not always present, polymorphisms, few morphological characters, and morphological stasis all contribute to problems associated with using solely morphology for algal taxonomy (Saunders 2005, Cianciola et al. 2010, De Clerck et al. 2013, Zinetti et al. 2013).

\subsubsection{Phylogenetics and Molecular Systematics}

Phylogenetic systematics is an approach to systematics that differs from the morphological species concept. The phylogenetic approach to systematics seeks to evaluate and order diversity based on evolutionary relationships between organisms (Moritz et al. 1990, Hillis et al. 1996, Wiley and Lieberman 2011). Morphological, anatomical, chemical and/or molecular data can all be used to produce phylogenies.

Character selection is a common issue when making species identifications based on 
morphology alone. Characters selected for assessment should be accessible and uncomplicated to study. These characters also must display variation that aptly reflects the specific relationship(s). They need to be independent of environmental influence and inherited from a shared common ancestor (homologous) (Lehmkuhl 2003). Although morphological and anatomical characters were dominant in red algal taxonomy in the past, as noted in the previous section species delimitation and identification based solely on morphological characters is not without its pitfalls.

Prior to the use of molecular markers, chemotaxonomy was also used to assess relationships between organisms based on their chemical compositions (carbohydrate, enzymes, secondary metabolites). However, various factors may confound the validity of species identifications based on chemotaxonomy (Cole and Sheath 1990, Mannheimer 1999). Different environmental factors and pressures (i.e. mineral deficiencies, grazing pressure, biofouling) have been attributed to observed variation of levels of chemical compounds in genetically identical individuals (Mannheimer 1999, Wright et al. 2000, Wright et al. 2004, Pelletreau and Targett 2008).

Molecular data has allowed an increase in relative speed and accessibility of a large number of taxonomically informative characters for phylogenetic comparison. Molecular data is the data of choice in most phylogenetic studies. It consists of DNA sequences that are homologous and variable (Moritz et al. 1990, Hillis et al. 1996). Issues such as subjectivity and phenotypic plasticity which arise from morphological data, are not a concern with sequence data. Random neutral molecular mutations (Kimura 1968) combined with effects of selection, lead to evolution of molecular characters. If the sequence data presented are composed of homologous genes, accurately aligned, and reliable (free from methodological artifacts), use of molecular data should increase reliability of the resulting phylogenies (Moritz et al. 1990, Hillis et al. 1996, Wiley and Lieberman 2011). 
Since the advent of molecular techniques, DNA sequence data have become widely used for species delimitations and inferring phylogenetic relationships. The phylogenetic species concept delineates species based on monophyletic relationships (Leliaert et al. 2014). DNA-based sequence delimitation is a particularly valuable tool for species identification in algae, which often display simple morphologies and the need for reproductive tissue that is not always available (Cianciola et al. 2010, Leliaert et al. 2014). One of the most popular markers used in molecular analyses for red and brown alga is the mitochondria-encoded cytochrome oxidase I gene (COI or cox1), (Hebert et al. 2003, Cianciola et al. 2010). However, other genes such as the nuclear-encoded large subunit ribosomal RNA genes (LSU), and the chloroplast-encoded RuBisCo ( $r b c \mathrm{~L})$ are also popular and can be assessed individually or conjointly to strengthen taxonomic interpretations (Maggs et al. 2007).

\subsubsection{Integrative and Molecular-Assisted Alpha Taxonomy}

"Their new idea that DNA barcoding can replace normal taxonomy for naming new species and studying their relationships is worse than bad, it is destructive." Will et al. (2005)

Opponents of singularly morphological or molecular-based taxonomy and systematics adapted an integrative approach (Dayrat 2005, Will et al. 2005, Padial et al. 2010, SchlickSteiner et al. 2010, Yeates et al. 2011). This multi-dimensional taxonomy is driven by numerous factors (Schlick-Steiner et al. 2010). One such driver is the failure of singularly morphological methods to accurately represent diversity. Another is the increased robustness of taxonomic considerations and increased knowledge of evolutionary history, when multiple methods demonstrate congruence.

Molecular-assisted alpha taxonomy (MAAT) has become an effective method for assessing biodiversity across a variety of organisms (Cianciola et al. 2010). MAAT takes morphometric data and assesses if morphological characteristics cluster with the respective molecular phylogenies. MAAT aims to answer two fundamental questions: 
1. Will molecular data support proposed conspecifics, or will they represent different entities?

2. Will molecular data support the morphological difference between interspecifics? (Cianciola et al. 2010).

Until recently, this multi-disciplinary approach was not widely used in phycology. However, the use of MAAT avoids some of the problems (mentioned in Section 1.2.1) of the sole use of morphological species delimitation.

\subsection{Rhodophyta}

\subsubsection{Red Algae: A Brief Introduction to the Biology and Life History}

The phylum Rhodophyta is an ancient lineage that has evolved into a diverse range of marine and freshwater algae with highly variable ultrastructures and morphologies (Yoon et al. 2006, Maggs et al. 2007). Red algae consist of approximately 7,100 recognized species (Guiry and Guiry 2016) that are inclusive of both uni- and multi-cellular taxa (Yoon et al. 2010, Guiry and Guiry 2016). Rhodophytes lack flagella and centrioles throughout their life histories. Floridean starch found in their cytoplasm acts as a carbohydrate storage products (van den Hoek et al. 1996). Their chlorophyll $a$ and carotenoids are masked by an array of phycobiliproteins (principally phycoerythrin and phycocyanin) that contribute to the varieties of red or purplish hues most members exhibit (Yoon et al. 2006, Seckbach and Chapman 2010). Their plastids have unstacked thylakoids, and lack a chloroplast encircling endoplasmic reticulum (Cole and Sheath 1990).

The majority of Rhodophyta have a complex triphasic life cycle: two diploid sporophyte phases (tetrasporophyte and carposporophyte) and a haploid gametophyte phase (Searles 1980, Yoon et al. 2010). This triphasic life history is thought to be a compensatory evolutionary trait linked to lack of flagellated gametes within the red algae (Searles 1980). 
The tetrasporophyte bares specialized structures (tetrasporangia), where meiotic division occurs and results in haploid tetraspores (van den Hoek et al. 1996). These haploid tetraspores are then released, becoming haploid male, female or bisexual gametophytes (van den Hoek et al. 1996). The male gametophyte produces spermatangial branches that bare spermatangia where spermatia are formed, released and passively transported to the female gametophyte. Syngamy occurs when the non-motile spermatium attaches to the trichogyne (extension of the egg, carpogonium), fuses and the spermatial nucleus fuses with the carpogonial nucleus. The carpogonium is borne on a branch system of the female gametophyte. The diploid zygote then matures into a carposporophyte, while still attached to the female, which mitotically produces diploid carpospores. These carpospores when released, becoming free-living tetrasporophytes (Saunders and Hommersand 2004).

\subsubsection{Red Algal Systematics: An Overview}

Linnaeus (1753) was the first to classify algae into the Cryptogamia, inclusive of fungi, ferns and mosses, a group based on lack of seed-like reproduction. In the following years, unlike Linnaeus who did not assign a taxonomic level to the algae, Gleditsch (1764) placed algae in the Algacea (Algaceae) as a class of plants. Justifications for these early classifications where singularly morphological (Moestrup 2001). It was Lamouroux (1813) who was first to distinguish algae not only on morphological characters but based on pigmentation, segregating certain red algae into the Floridées. However, Harvey (1836) redefined these divisions: Chlorospermae (green algae), Diatomaceae (diatoms and desmids), Melanospermae (brown algae), and Rhodospermae (red algae) (Moestrup 2001, Saunders and Hommersand 2004).

Lamouroux (1813), C. Agardh (1817, 1824), Harvey (1836), Kützing (1843) and J. Agardh $(1842,1876)$ made innovative classifications based on pigmentation, vegetative 
anatomy, and macroscopic reproductive structures. Red algae were traditionally divided into two classes the Bangiophyceae and the Floridiophyceae (the Bangiophyceae are out of the scope of this thesis). The Floridiophyceae, inclusive of approximately 5,800 species, is the most taxonomically diverse of the red algae (Yoon et al. 2010). However, the first classification system of florideophycidean red algae reflective of taxa relationships came from Bornet and Thuret's (1867) detailed observations of syngamy patterns and Schmitz's (1883) characterization of carposporophyte development (Cole and Sheath 1990). With these observations Schmitz (1892) divided red algae into four orders: Rhodymeniales, Cryptonemiales, Nemaliales, and Gigartinales, based on gominoblast (diploid carposoprophyte tissue) development and auxiliary cell presence, position or absence (Cole and Sheath 1990, Lehmkuhl 2003).

Given that reproductive structures and morphologies were the main drivers of taxonomic placement of red algae, implementation of molecular markers has allowed for deeper understanding of their systematics (Cianciola et al. 2010, De Clerck et al. 2013). The monophyly of Rhodophyta is strongly supported by multiple gene trees (Yoon et al. 2010). Previously sorted into two classes Bangiophyceae (six orders: Bangiales, Compsopogonales, Cyanidiales, Erythropeltidales, Porphyridiales, and Rhodochaetales) and Florideophyceae (Gabrielson et al. 1985, Freshwater et al. 1994, Saunders and Hommersand 2004) based solely on morphological observation (Yoon et al. 2010), molecular studies have shown monophyly of the Florideophyceae (Oliveira and Bhattacharya 2000, Yoon et al. 2002, Yoon et al. 2010).

\subsubsection{Importance of Red Algae}

Rhodophytes are distributed from the Antarctic to the Arctic, and inhabit from the upper-littoral zone to the fringes of the photic zone (van den Hoek et al. 1996, Lopez- 
Bautista 2010). In marine ecosystems, red algae provide a source of oxygen for the environment, heterotrophic species with a food source, a settlement target for epiphytic species, and shelter, nesting and egg release sites for numerous species (Gurgel and Lopez -

Bautista 2007). Crustose and calcareous red algae provide structural integrity, settlement stratum, protection from wave impact crucial for various (coral, algal, etc.) reef habitats (Marsh 1970, Björklund et al. 1995, Gurgel and Lopez - Bautista 2007). Not only are the Rhodophyta ecologically important, they also play a role economically as well.

The Rhodophyta are considered to be of extreme economic value in some countries and act as sources of polysaccharide-based biomaterials which are unable to be synthetically produced due to their complexity (Seckbach and Chapman 2010, Francavilla et al. 2015). The sulfated galactans, agar and carrageenan, within the walls of red algae are used to produce various products such as agarose gels (Seckbach and Chapman 2010).

\subsection{An Introduction to Plocamium}

\subsubsection{Biology and Life History of Plocamium}

Plocamium Lamouroux (Lamouroux 1813) is a cosmopolitan genus consisting of 51 species (Guiry and Guiry 2016) that span from the Arctic to the Antarctic in intertidal and subtidal waters (Wynne 2002b). Plocamium is characterized as having erect, bilaterally compressed thalli with flat branched fronds that have margins bearing repeating alternating series of two or more ramuli (Womersley 1971, Saunders and Lehmkuhl 2005). The lowest ramulus in the series (basal ramuli) commonly remains unbranched, and its morphology (margin, curvature and shape) is used as an identification character for some species (Womersley 1971). The upper ramulus in the series, although it can remain dormant, most frequently develops into a lateral branch. As in many Rhodophyta, their reproductive 
structures can also be useful in species identification. Plocamium cystocarps lack an ostiole, a pore for carpospore release, can be sessile or pedunculate, single or clustered, located in the axils or along the abaxial or adaxial margins of the main thallus (Womersley 1971, South and Adams 1979, Adams 1994, Saunders and Lehmkuhl 2005). Tetrasporangia position is highly variable, located within the axils or along the abaxial or adaxial ramuli margins, and are contained within specialized stichidia, which have the possibility of being seriate or biseriate (Womersley 1971, Dixon and Irvine 1977, Saunders and Lehmkuhl 2005).

\subsubsection{History of Systematics of Plocamium}

Plocamium was originally assigned in the family Plocamieae (Kützing 1843).

However, based on observed development of the procarp/cystocarp (the female reproductive branches that usually consist of carpognium, trichogyne, and sometimes auxillary cells), Schmitz (1892) assigned Plocamium to the Rhodymeniaceae of the Rhodymeniales. Due to the distinct differences in cystocarp development (presence of accessory auxiliary cells, three-celled carpogonia branching, procarpial, and zonate tetrasporangia) it was placed in the Sphaerococcaceae of the Sphaerococcales (Sjöstedt 1926). Plocamium was maintained within the Sphaerococcaceae but moved it to the Nemastomales, an order inclusive of nonaccessorized auxiliary celled, non-procarpial algae (Kylin 1928). However, they were then placed in the Gigartinales under the proposed family Plocamiaceae due to fundamental differences in carpospores production (Kylin 1930). This nomenclature held until Saunders and Kraft (1994) using SSU rRNA gene sequences proposed the order Plocamiales inclusive of Plocamium and its adelphoparasite Plocamiocolax Setchell.

\subsubsection{Natural Products and Plocamium}

Natural products chemistry is the discovery, characterization and cataloging of chemical substances found in nature (Maschek and Baker 2008). The term 'natural product' 
refers to a substance generated by a living organism, and can be used synonymously with 'secondary metabolites' (Maschek and Baker 2008). Classification of secondary metabolites is dependent upon their biosynthetic origins. These secondary compounds are numerous and serve various functions. Terpenes, alkaloids, and shikimates are amongst the natural products produced by algae and can serve as anti-herbivore defenses and ultraviolet radiation barriers (Maschek and Baker 2008). Macroalgae account for $~ 20 \%$ (nearly 3,000 natural products) of all known chemistry within the marine environment (Maschek and Baker 2008).

Plocamium has had much interest from numerous fields due to its high content of secondary compounds (Wynne 2002b, Paradas et al. 2015). Plocamium produces acyclic and cyclic halogenated monoterpenes (San-Martín and Rovirosa 1986, Afolayan et al. 2009, Timmers et al. 2012, Young et al. 2013, Paradas et al. 2015). Within P. cartilagineum there have been over 50 unique secondary metabolites identified, $95 \%$ of which are polyhalogenated monoterpenes, and have pharmalogical properties (Kladi et al. 2004, Young et al. 2013).

This rich chemistry may provide another possible way to identify cryptic species (Young et al. 2013). A taxonomic investigation of Plocamium species in Japan, revealed intracellular acidity could be a taxonomically informative physiological property (Yano et al. 2004). A study investigating the P. cartilagineum from the western Antarctic Peninsula revealed $\mathrm{COI}$ and $r b c \mathrm{~L}$ analyses differentiated the alga in to two phylogroups, however chemical analyses divided each further into one of five chemogroups (Young et al. 2013). The authors indicated there were no observable site-specific environmental factors to influence this pattern, and suggested that the chemical diversity could be a signal of the presence of cryptic species or that cryptic speciation is occurring. However other algal species do show evidence of environmental dependence of internal chemistry (Naylor et al. 
1983) and some believe that identification through chemistry may not allow for the resolution of the taxonomy (San-Martín and Rovirosa 1986, Cole and Sheath 1990).

\subsubsection{Plocamium in New Zealand}

Currently there are seven reported species of Plocamium in New Zealand: Plocamium angustum (J. Agardh), P. cartilagenium (L.) P.S. Dixon, P. cirrhosum (Turner) M.J. Wynne, P. hamatum (J. Agardh), P. hookeri (Harvey), P. leptophyllum (Kützing), and P. microcladioides (Womersley 1971, South and Adams 1979, Adams 1994, Wynne 2002a). These species are distributed throughout New Zealand and range as far north as the Kermedecs down to the Subantarctic islands (South and Adams 1979, Adams 1994, Nelson et al. 2013).

These species descriptions are based on Hooker and Harvey (1895), Womersley (1971), South and Adams (1979), Adams (1994) and Wynne (2002b).

\section{Plocamium angustum}

Physical Description: Thallus, with numerous erect, linear, slender axes developing from the base, up to $25 \mathrm{~cm}$ high. Axes commonly $0.5-1 \mathrm{~mm}$ broad (in rare cases up to $1.5 \mathrm{~mm}$ ), with alternating pairs of ramuli. With $1-1.5 \mathrm{~mm}$ long, less than $0.5 \mathrm{~mm}$ wide, awl-shaped basal ramuli. Abaxial margin of basal ramuli usually non-serrate, but occasionally has small spines or serrations. Cystocarps 600-900 $\mu \mathrm{m}$ in diameter, globular, flat to slightly varicose, sessile on adaxial base of ramuli or on adjacent axis. In male plants, spermatangia cover the surface of ramuli near the apices of the branch. Stichidia are basally branched and become tufts that grow with age in the axils of the ramuli and extend along the adaxial margin. The area of the stichidia that bears the sporangium is $60-100 \mu \mathrm{m}$ thick, unbranched, swollen, slender, cylindrical, and slightly tapering with a slender stalk. The tetrasporangia are 50-70 $\mu \mathrm{m}$ long and 25-30 $\mu \mathrm{m}$ wide.

New Zealand Distribution: Chathams, North Island, South Island, Stewart Island, Subantarctic Islands

Type Locality: Australia

Type: Herb. Agardh LD, No. 28026 


\section{Plocamium cartilagineum}

Physical Description: Thallus up to $20 \mathrm{~cm}$, slender, and densely branched. Axes width ranges between $1-1.5 \mathrm{~mm}$. Ramuli alternating 3-4 per series is most common, however there are instances of alternating pairs or as many as 10 ramuli per alternating series. All ramuli are most commonly branched. The upper most ramuli and occasionally second ramuli develop into long laterals. The lowest basal ramuli is most often $1-2 \mathrm{~mm}$ long, $0.25 \mathrm{~mm}$ or less wide, non-serrate, sometimes curved but mostly linear to awl-shaped. In the female, cystocarps are $0.5-0.75 \mathrm{~mm}$ in diameter, globular, smooth, sessile, located on the ramuli margins or in or adjacent to the axils. Stichidia are simple and lanceolate with branching upper ends, commonly lengths range from $0.25-0.4 \mathrm{~mm}$ but can be as short as $0.15 \mathrm{~mm}$ or as long as $1 \mathrm{~mm}$, and widths average $0.1 \mathrm{~mm}$. Tetrasporangia range from $40-50 \mu \mathrm{m}$ in length and $27-32 \mu \mathrm{m}$ wide, are oval and arranged in two rows.

New Zealand Distribution: Chathams, North Island, South Island, Stewart Island, Subantarctic Islands

Type Locality: Northern Europe

Type: L $(910,184 \ldots 14)$

\section{Plocamium cirrhosum}

Physical Description: Erect slender thallus reaching up to $30 \mathrm{~cm}$ high. Axes $1-2 \mathrm{~mm}$ wide but can be found up to $2.5 \mathrm{~mm}$, appearing ribbed in the mid and lower axes due to lightening of color in the central area. Ramuli $1-2 \mathrm{~mm}$ long (can reach up to $3 \mathrm{~mm}$ ) straight to slight curled, with strong and even serrations on the curled abaxial margin. Lowest most basal ramuli width is on average $0.5 \mathrm{~mm}$ at the base. Cystocarps are most commonly located along the abaxial margin of the lowest basal ramuli but can also be within the axis and along the adaxial edge ramuli. They are approximately $0.75 \mathrm{~mm}$ in diameter, sessile, globular, and slightly raised when dry. Axils of upper ramuli bare spermatangia that are densely branched. Stichidia in clusters in the axils, along the abaxial margin of the upper ramuli or along the adaxial margin of the lowest basal ramuli, approximately $1.25 \mathrm{~mm}$ high and dense in mostly uniform branches that are about $100 \mu \mathrm{m}$ in diameter. The apices of the stichidial branches bare dense tetrasporangia, which on average can be $50-65 \mu \mathrm{m}$ long and $35-45 \mu \mathrm{m}$ in width.

New Zealand Distribution: Chathams, North Island, South Island

Type Locality: Dusky Sound, Fiordland Region, New Zealand

Type: BM 44253

\section{Plocamium hamatum}

Physical Description: Thallus bright rose pink, softly textured, up to $15 \mathrm{~cm}$ high, highly branched with axes up to $1.5 \mathrm{~mm}$ wide. Ramuli alternate in series of 3, with a non-serrate and commonly strongly recurved lowest basal ramuli. Cystocarps are sessile and globular located along the margins. Male plants are non-identified. Stichidia are pedunculate along the margins and often curled. 
New Zealand Distribution: Kermadec Islands

Type Locality: Norfolk Island

Reference specimens: WELT A9524

Plocamium spp.

Physical Description: Undescribed

New Zealand Biogeographical Distribution: New Zealand

Type Locality:

Type:

\section{Plocamium leptophyllum}

Physical Description: Usually epiphytic most commonly on other algae. Bases indefinite, and give rise to dense, entangled, clustered branches up to $15 \mathrm{~cm}$ high. Axes average $0.5 \mathrm{~mm}$ wide and often full of bends and curves. Ramuli usually alternate in series of 4-5 but occasionally triplets, all branching except the lowest basal ramuli. The lowest basal ramuli is non-serrated and frequently recurved (hooked), $1-1.5 \mathrm{~mm}$ long, and on average $50 \mu \mathrm{m}$ wide but can be as wide as $100 \mu \mathrm{m}$ at the base. Cystocarps are pedunculate. Stichidia on average range from $0.2-0.25 \mathrm{~mm}$ in length, but can reach up to $0.75 \mathrm{~mm}$. They are $0.75-1 \mathrm{~mm}$ wide and can be either single or grouped in the axis or on the abaxial margin of ramuli. They can be simple or branched, lanceolate with a short pedicle and most commonly with an acute, sterile tip. Tetrasporangia are approximate $40 \mu \mathrm{m}$ long, oval, and arranged in either one or two rows.

New Zealand Distribution: South Island, North Island (from South of Taranaki), Stewart Island, Subantarctic Islands

Type Locality: Georgetown, Tasmania

Type: L 941, 181_.. 471

\section{Plocamium microcladioides}

Physical Description: Rhizoidal base bearing an entangled branched thallus up to $15 \mathrm{~cm}$ high. Axes have widths that range from $0.75-1 \mathrm{~mm}$, are cylindrical or slightly tapering, and become oval to flattened and bare towards the base. Ramuli alternate in series of triplets (rarely in pairs) all but the basal ramuli branched. The basal ramuli is simple and is on average $2 \mathrm{~mm}$ long. Cystocarps are approximately $0.5 \mathrm{~mm}$ in diameter found along the abaxial margin of the ramuli or in the axis. Stichidia can reach up to $200 \mu \mathrm{m}$, are club-shaped and unbranched. The entire branch becomes fertile. Tetrasporangia are biseriate.

New Zealand Distribution: Chathams, Southern North Island, South Island, Stewart Island

Type Locality: Jackson's Bay, South Westland, New Zealand 
However, it is believed that this diversity is underestimated (Womersley 1971, South and Adams 1979, Nelson et al. 2013), and species may be misidentified based on superficial likeness to Northern hemisphere algae (Womersley 1971, Yano et al. 2004). Studies in other parts of the world have uncovered cryptic diversity within Plocamium (Saunders and Lehmkuhl 2005). Of particular interest is $P$. cartilagineum, which was thought to be cosmopolitan but consists of four distinct groups (Saunders and Lehmkuhl 2005). With its type locality being Northern Europe, it seems logical to question if this could be the same species in New Zealand. Nelson (2013) notes in her description of Plocamium "it is clear that further work is required to understand both diversity here and the correct names to apply to species.”

Given that the taxonomy of Plocamium within New Zealand has been questioned yet not thoroughly investigated, it would be beneficial to investigate this alga. This will allow for a more complete picture of the genus within New Zealand and the relationship they have with other regions of the world. 


\section{Research Chapter:}

\subsection{Abstract:}

Traditional morphological-based studies of macroalgal diversity have had difficulty accurately discerning species, and consequently their distributions, and evolutionary relationships. Molecular methods in species delimitation have aided in their taxonomy. Molecular-assisted alpha taxonomy is an integrative approach that can be useful in circumstances where morphology is not adequate to accurately delimit species. Morphological studies of the red alga Plocamium (Plocamiales, Rhodophyta) have failed to accurately discern diversity of species. Given that there has never been a multimethodological study on Plocamium species within New Zealand, there is uncertainty about the validity of its presently described species. This study is the first to use molecular-assisted alpha taxonomy to investigate these uncertainties. New Zealand specimens were analyzed using partial COI, $r b c \mathrm{~L}$, LSU rRNA, and combined sequences to determine putative species and evolutionary relationships. Maximum likelihood and Bayesian phylogenies were constructed, three species delimitation methods (ABGD, GMYC and bPTP) were conducted using the COI data set, and morphological characters analyzed (width of main axis, width of lowest basal ramuli, length of lowest basal ramuli, number of alternating series of ramuli, average number of ramuli per alternating series, curvature of basal ramuli and serrations present or absent from basal ramuli) and compared. Eleven candidate genetic species groups were delimited. Morphometric analyses indicated morphology reflects species diversity when multiple measurements of multiple characters are used. Phylogenetic analyses revealed possible monophyly of candidate species C-K in New Zealand, and possibly close relationships to species found in Australia, Chile, and Taiwan. However these relationships were poorly supported. The results of this study indicate that Plocamium diversity within 
New Zealand has been underestimated. This study provides the first steps in discovering the true species diversity of Plocamium within New Zealand.

Key Words: Plocamium, molecular-assisted alpha taxonomy, New Zealand, species delimitation, COI, LSU rRNA, $r b c$ L, phylogenetics, Plocamiales, integrative taxonomy

\subsection{Introduction:}

Traditionally, macroalgal systematics has relied on morphological studies and investigations to delimit species. Convergent morphological evolution, phenotypic plasticity, the need for reproductive tissues that are not always present, polymorphisms, few morphological characters, and morphological stasis all have the potential to contribute to problems associated with solely using morphology for algal taxonomy (Saunders 2005, Cianciola et al. 2010, De Clerck et al. 2013, Zinetti et al. 2013, Leliaert et al. 2014). Molecular data has allowed an increase in relative speed and accessibility of a large number of taxonomically informative characters for phylogenetic comparison.

Molecular-assisted alpha taxonomy (MAAT) has become an effective method for assessing biodiversity across a variety of organisms (Cianciola et al. 2010). MAAT takes morphological data and assesses if morphological characteristics are congruent with molecular phylogenies and assists in defining species. Current trends are towards these integrative approaches to establish increasingly robust taxonomic hypotheses (Cianciola et al. 2010, Padial et al. 2010, Robuchon et al. 2015, Machín - Sánchez et al. 2016).

The cosmopolitan genus Plocamium Lamouroux is a member of the Plocamiales (Saunders and Kraft 1994), along with its adelphoparasite Plocamiocolax Setchell (Saunders and Kraft 1994, Guiry and Guiry 2016). Plocamium is characterized as having erect, bilaterally compressed thalli with flat branched fronds that have margins bearing repeating alternating series of two or more ramuli (Womersley 1971, Saunders and Lehmkuhl 2005). 
Their reproductive structures include ostiole-less cystocarps that can be located in specialized fertile branches or along the margins of ramuli, and stichidia of varying morphologies that bare tetrasporangia (Dixon and Irvine 1977). Although within Plocamium there are 108 species (and infraspecific) names lodged within AlgaeBase, only 51 species are currently accepted taxonomically (Guiry and Guiry 2016). Morphological and anatomical vegetative characters, morphology of the reproductive structures, and biogeography are characters used to aid in identifying Plocamium species (Wynne 2002b, Saunders and Lehmkuhl 2005, Cremades et al. 2011). Traditionally, most Plocamium are differentiated into species based on the color and consistency of the thallus, number of ramuli in an alternating series, the length, width and morphology of the lowest basal ramuli within an alternating series, morphology of the stichidia, and arrangement of cystocarps (Simons 1964, Womersley 1971, South and Adams 1979, Gabrielson et al. 1985, Adams 1994, Wynne 2002b, Saunders and Lehmkuhl 2005, Cremades et al. 2011). Studies have shown that Plocamium exhibits not only interspecific but also significant intraspecific morphological variation, making species identification and delimitations based solely on morphological characters difficult (Saunders and Kraft 1994, Fredericq et al. 1996, Goff et al. 1996, Yano et al. 2004, Saunders and Lehmkuhl 2005, Cremades et al. 2011).

Molecular data have become increasingly used in conjunction with morphological and anatomical characters to overcome complications in species delimitations and identifications within Plocamium. Numerous molecular markers, including the mitochondria-encoded cytochrome oxidase I gene (COI or cox1) (Cremades et al. 2011, Young et al. 2013), the nuclear-encoded large subunit ribosomal RNA genes (LSU)(Saunders and Lehmkuhl 2005), and the plastid-encoded large subunit of RuBisCo $(r b c \mathrm{~L})$ (Fredericq et al. 1996, Yano et al. 2004), have been used to identify specimens, describe new species, and elucidate interspecific relationships in Plocamium. DNA barcoding and molecular analyses have been 
demonstrated to be helpful taxonomic tools within Plocamium, validating some species identifications based on morphological characters (Yano et al. 2004) and revealing cryptic species in others (Saunders and Lehmkuhl 2005, Cremades et al. 2011).

Plocamium is one of the most common and distinct red alga found throughout New Zealand (South and Adams 1979). Although most abundant in the subtidal zone, Plocamium can also dominate communities in the mid- to lower littoral intertidal zones. Currently there are seven species reported in New Zealand, based on morphology: Plocamium angustum (J. Agardh), P. cartilagenium (L.) P.S. Dixon, P. cirrhosum (Turner) M.J. Wynne, P. hamatum (J. Agardh), P. hookeri (Harvey), P. leptophyllum (Kützing), and P. microcladioides (G.R. South \& N.M. Adams). A previous taxonomic study on Plocamium within New Zealand based solely on morphological data, revealed a new species (P. microcladioides) (South and Adams 1979) and indicated uncertainty about identification of others based on overlapping morphological features, which is supported by other authors (South and Adams 1979, Adams 1994, Nelson 2013).

This study focuses on elucidating the taxonomy of Plocamium from New Zealand. Given that there has never been a multi-methodological study on Plocamium species within New Zealand, there is uncertainty about the validity of its presently described species. An integrative approach, using molecular data and morphometric analyses is needed to further understand the genus within New Zealand. To delineate species diversity and distribution of Plocamium within New Zealand, a molecular-assisted investigation was conducted using partial COI, $r b c \mathrm{~L}$, and LSU molecular markers and multivariate analyses of morphological characters to determine if genetic variation reflects morphological variation. 


\subsection{Materials and Methods:}

\subsubsection{Study area and sample collection}

Specimens were collected from various locations throughout New Zealand. NIWA staff also provided various specimens for morphological and molecular analyses. A list of all samples used within the study is provided (Table 1). Samples were collected from drift, intertidal, and subtidal habitats. Preliminary species identifications were based on examination of morphological characteristics (Adams 1994). For each specimen collected, a voucher was made for morphometric analyses and a respective subsample from each voucher was preserved in silica gel for molecular analyses.

\subsubsection{DNA extraction, amplification and sequencing}

DNA was extracted using a modified CTAB protocol (Zuccarello and Lokhorst 2005). The extracted DNA was then stored at $-20^{\circ} \mathrm{C}$. Three DNA regions were amplified: the mitochondrial-encoded cytochrome c oxidase subunit I (COI), nuclear-encoded large subunit ribosomal RNA genes LSU), and the plastid-encoded large subunit of RuBisCo (rbcL).

PCR amplification was performed for each marker with a final volume of $30 \mu 1$ using 1 $\mu 1$ of extracted DNA, 1x Reaction Buffer, 2.5 mM dNTP's, $3.3 \mathrm{mM} \mathrm{MgCl}_{2}, 0.03 \%$ BSA, 0.25 pmol of each primer, and $1 \mathrm{U}$ Taq polymerase (Bioline Reagents Limited). The partial COI gene was amplified using the primers GAZF1 and GAZR1 (Saunders 2005). The LSU gene was amplified using three overlapping fragments $(\mathrm{X}, \mathrm{Y}, \mathrm{Z})$ using primers: T01/T13, T04/T08 and T05/T15 respectively (Harper and Saunders 2001). The $r b c \mathrm{~L}$ gene was amplified as two overlapping fragments. The primer pair F57/R753 was used for the first fragment, and F577/R1153 was used for the second (Freshwater and Rueness 1994). PCR was performed with an initial denaturation step of $94^{\circ} \mathrm{C}$ for 5 mins. This was followed by 1 min steps of $94^{\circ} \mathrm{C} / 45^{\circ} \mathrm{C} / 72^{\circ} \mathrm{C}$ each, cycled 36 times. A final extension at $72^{\circ} \mathrm{C}$ for 5 mins was used. The PCR products were then electrophoresed in a 1\% agarose gel and stained with 
ethidium bromide. PCR products were cleaned using Exo SAP-IT (Affymetrix, USB product, USA) following manufacturers protocols. Amplicons were sequenced commercially (Macrogen Inc. Seoul, Korea). Forward and reserve sequences were edited using Geneious v9.1 (Biomatters Ltd, USA). 
Table 1. A list of all specimens used within the study. No.= Indentifcation number attributed to specimen. Current Name $=$ Taxonomic name attributed to the specimen based on morphology or collectors identification. Location $=$ Collection location $(\mathrm{CI}-$ Chatham Island, NI - North Island, SI - South Island. Collector $=$ Collector of the material (Collectors: Madeline W. Cooper - MWC, Maren Pruess - MP, Wendy A. Nelson - WAN, Roberta D’Archino - RDA, Malcom Francis - MF), Date= Collection date. Group $=$ Species group assigned to based on the results of species delimitation methods. WELT $=$ Te Papa voucher number .

\begin{tabular}{|c|c|c|c|c|c|c|}
\hline No. & Current Name & Location & Collector & Date & Group & WELT \\
\hline A1 & Plocamium angustum & Marfells Beach, Marlborough, SI & MWC & 21.03 .15 & A & - \\
\hline $\mathrm{A} 2$ & Plocamium angustum & Marfells Beach, Marlborough, SI & MWC & 21.03 .15 & $\mathrm{~A}$ & - \\
\hline A3 & Plocamium microcladioides & Marfells Beach, Marlborough, SI & MWC & 21.03 .15 & $\mathrm{~K}$ & - \\
\hline A4 & Plocamium microcladioides & Marfells Beach, Marlborough, SI & MWC & 21.03 .15 & $\mathrm{~K}$ & - \\
\hline A5 & Plocamium cirrhosum & Marfells Beach, Marlborough, SI & MWC & 21.03 .15 & $\mathrm{E}$ & - \\
\hline A6 & Plocamium cirrhosum & Marfells Beach, Marlborough, SI & MWC & 21.03 .15 & $\mathrm{E}$ & - \\
\hline A10 & Plocamium microcladioides & Akitio, Manawatu, NI & MWC & 02.02 .15 & $\mathrm{H}$ & - \\
\hline A11 & Plocamium microcladioides & Akitio, Manawatu, NI & MWC & 02.02 .15 & $\mathrm{~K}$ & - \\
\hline A12 & Plocamium microcladioides & Akitio, Manawatu, NI & MWC & 02.02 .15 & $\mathrm{H}$ & - \\
\hline A15 & Plocamium microcladioides & Mahia, Hawkes Bay, NI & MWC & 04.02 .15 & $\mathrm{~K}$ & - \\
\hline A16 & Plocamium microcladioides & Waimarama, Hawkes Bay, NI & MWC & 04.02 .15 & $\mathrm{~K}$ & - \\
\hline A17 & Plocamium cirrhosum & Waimarama, Hawkes Bay, NI & MWC & 04.02 .15 & $\mathrm{E}$ & - \\
\hline A18 & Plocamium cirrhosum & Waimarama, Hawkes Bay, NI & MWC & 04.02 .15 & $\mathrm{E}$ & - \\
\hline A23 & Plocamium cirrhosum & Whangara, Gisborne, NI & MWC & 05.02 .15 & $\mathrm{E}$ & - \\
\hline A24 & Plocamium cirrhosum & Whangara, Gisborne, NI & MWC & 05.02 .15 & $\mathrm{E}$ & - \\
\hline A26 & Plocamium angustum & Makorori, Gisborne, NI & MWC & 05.02 .15 & $\mathrm{H}$ & - \\
\hline A30 & Plocamium spp. & Three Kings Islands & RDA & 18.04 .13 & $\mathrm{~F}$ & ASN694 \\
\hline A31 & Plocamium spp. & South West Island, NZL & RDA & 13.04 .13 & $\mathrm{E}$ & ASN516 \\
\hline A33 & Plocamium spp. & $\begin{array}{l}\text { Princess Islands, Three Kings } \\
\text { Islands }\end{array}$ & RDA & 10.04 .13 & $\mathrm{~F}$ & ASN344 \\
\hline A40 & Plocamium spp. & Three Kings Islands & $\mathrm{MF}$ & 18.04 .13 & $\mathrm{~F}$ & ASN660 \\
\hline
\end{tabular}




\begin{tabular}{|c|c|c|c|c|c|c|}
\hline A41 & Plocamium spp. & $\begin{array}{l}\text { Auckland Islands, Enderby Island, } \\
\text { Sandy Bar }\end{array}$ & WAN & 17.02 .13 & $\mathrm{~K}$ & ASN151 \\
\hline A46 & Plocamium spp. & Three Kings Islands & RDA & 13.04 .13 & $\mathrm{E}$ & ASN515 \\
\hline A50 & Plocamium cirrhosum & Marsden Point, Northland, NI & RDA & 01.10 .09 & $\mathrm{~B}$ & SS1137 \\
\hline A51 & Plocamium spp. & Three Kings Islands & RDA & 11.04 .13 & $\mathrm{~B}$ & ASN434 \\
\hline A54 & Plocamium angustum & Matikona, Wairarapa, NI & MWC & 03.09 .15 & $\mathrm{~K}$ & - \\
\hline A59 & Plocamium spp. & Moa Point, Wellington, NI & MWC & 14.09 .15 & $\mathrm{G}$ & - \\
\hline A62 & Plocamium spp. & Marfells Beach, Marlborough, SI & MWC & 21.09 .15 & $\mathrm{~B}$ & - \\
\hline A66 & Plocamium angustum & Marfells Beach, Marlborough, SI & MWC & 21.09 .15 & $\mathrm{~K}$ & - \\
\hline A70 & Plocamium spp. & Marfells Beach, Marlborough, SI & MWC & 21.09 .15 & $\mathrm{~B}$ & - \\
\hline A72 & Plocamium spp. & Marfells Beach, Marlborough, SI & MWC & 21.09 .15 & $\mathrm{~A}$ & - \\
\hline A73 & Plocamium cirrhosum & Moa Point, Wellington, NI & MWC & 07.01 .16 & $\mathrm{E}$ & - \\
\hline A74 & Plocamium spp. & Moa Point, Wellington, NI & MWC & 07.01 .16 & $\mathrm{G}$ & - \\
\hline A77 & Plocamium spp. & Bluff, Sterling, Southland, SI & MWC & 24.02 .16 & $\mathrm{E}$ & - \\
\hline A80 & Plocamium spp. & Curio Bay, Southland, SI & MWC & 24.02 .16 & $\mathrm{H}$ & - \\
\hline A82 & Plocamium spp. & Taylor's Mistake, Canterbury, SI & MWC & 28.02 .16 & $\mathrm{~B}$ & - \\
\hline A83 & Plocamium spp. & Taylor's Mistake, Canterbury, SI & MWC & 28.02 .16 & $\mathrm{~B}$ & - \\
\hline A84 & Plocamium spp. & Taylor's Mistake, Canterbury, SI & MWC & 28.02 .16 & $\mathrm{C}$ & - \\
\hline A85 & Plocamium spp. & Papatowhai, Catlins, SI & MWC & 24.02 .16 & $\mathrm{H}$ & - \\
\hline A87 & Plocamium spp. & Marfells Beach, Marlborough, SI & MWC & 29.02 .16 & $\mathrm{~A}$ & - \\
\hline A88 & Plocamium spp. & Marfells Beach, Marlborough, SI & MWC & 29.02 .16 & $\mathrm{~K}$ & - \\
\hline A89 & Plocamium spp. & Waipapa Point, Southland, SI & MWC & 24.02 .16 & I & - \\
\hline A90 & Plocamium spp. & Waipapa Point, Southland, SI & MWC & 24.02 .16 & $\mathrm{I}$ & - \\
\hline A94 & Plocamium spp. & Moreaki, Otago, SI & MWC & 26.02 .16 & $\mathrm{~J}$ & - \\
\hline A95 & Plocamium spp. & Shag Point, Otago, SI & MWC & 26.02 .16 & $\mathrm{~K}$ & - \\
\hline A96 & Plocamium spp. & Shag Point, Otago, SI & MWC & 26.02 .16 & A & - \\
\hline A98 & Plocamium angustum & Kaka Point, Catlins, SI & MWC & 25.02 .16 & A & - \\
\hline A100 & Plocamium spp. & Kaka Point, Catlins, SI & MWC & 25.02 .16 & $\mathrm{~K}$ & - \\
\hline $\mathrm{B} 2$ & Plocamium spp. & Owenga House, CI & MP & 18.03 .16 & $\mathrm{~J}$ & - \\
\hline
\end{tabular}




\begin{tabular}{|c|c|c|c|c|c|c|}
\hline B3 & Plocamium spp. & Waitangi West, CI & MP & 19.03 .16 & $\mathrm{~J}$ & - \\
\hline B4 & Plocamium spp. & Waitangi West, CI & MP & 19.03 .16 & I & - \\
\hline B5 & Plocamium spp. & Chatham Hotel, Waitangi, CI & MP & 17.03 .16 & $\mathrm{E}$ & - \\
\hline B7 & Plocamium spp. & Chatham Hotel, Waitangi, CI & MP & 17.03 .16 & $\mathrm{E}$ & - \\
\hline B8 & Plocamium spp. & Chatham Hotel, Waitangi, CI & MP & 17.03 .16 & A & - \\
\hline B9 & Plocamium spp. & Kaingaroa Seal Colony, CI & MP & 20.03 .16 & $\mathrm{~J}$ & - \\
\hline B10 & Plocamium spp. & Kaingaroa Seal Colony, CI & MP & 20.03 .16 & $\mathrm{~J}$ & - \\
\hline B11 & Plocamium spp. & Kaingaroa Seal Colony, CI & MP & 20.03 .16 & $\mathrm{~J}$ & - \\
\hline $\mathrm{R} 2$ & Plocamium spp. & NZL & RDA & & $\mathrm{K}$ & ASQ12 \\
\hline R9 & Plocamium spp. & $\begin{array}{l}\text { Marlborough Sound, Marlborough, } \\
\text { SI }\end{array}$ & RDA & & $\mathrm{B}$ & ASO155 \\
\hline $\mathrm{R} 12$ & Plocamium spp. & Northland, NI & RDA & & $\mathrm{B}$ & ASO214 \\
\hline R13 & Plocamium spp. & NZL & RDA & & $\mathrm{B}$ & ASO256 \\
\hline R17 & Plocamium spp. & NZL & RDA & & $\mathrm{K}$ & FOO2T29 \\
\hline R18 & Plocamium spp. & NZL & RDA & & $\mathrm{A}$ & ASP146 \\
\hline R19 & Plocamium spp. & NZL & RDA & & $\mathrm{B}$ & ASQ002 \\
\hline R20 & Plocamium spp. & NZL & RDA & & $E$ & ASP144 \\
\hline R23 & Plocamium spp. & NZL & RDA & & $\mathrm{K}$ & F044 \\
\hline R24 & Plocamium spp. & NZL & RDA & & $\mathrm{K}$ & ASP145 \\
\hline $\mathrm{R} 25$ & Plocamium spp. & NZL & RDA & & $\mathrm{E}$ & F050 \\
\hline JB21 & Plocamium spp. & NZL & WAN & & $\mathrm{D}$ & JB21 \\
\hline JB22 & Plocamium spp. & NZL & WAN & & $\mathrm{I}$ & JB22 \\
\hline JB23 & Plocamium spp. & NZL & WAN & & $\mathrm{I}$ & JB23 \\
\hline
\end{tabular}




\subsubsection{Multiple sequence alignments and phylogenetic analyses}

Edited sequences were used for alignments. BLAST searches of all sequences were conducted to verify generic matches. Alignments were constructed in Geneious v9.1 using MAFFT (Katoh et al. 2002) with the default parameters. Alignments were checked and realigned by eye and edited when necessary. The COI (663 bp) alignment had 109 sequences, including 79 sequences of Plocamium from New Zealand (Table 1) and a selection of 30 others from Genbank (Supplementary Table A.1). Identical sequences were determined and removed from subsequent analyses (Supplementary Table A.2). If a partial COI sequence was identical to a COI sequences in the reduced dataset the specimen was assigned to that "candidate species" for further molecular and morphological analyses. Phylogenetic analyses were preformed using the COI dataset $(n=80)$. Representative specimens were selected from each of the COI candidate species groups (see below) to construct a $r b c \mathrm{~L}$ (1083 bp) alignment that included 17 specimens from New Zealand (Supplementary Table A.3.1) and 21 others from Genbank (Supplementary Table A.3.2), plus a LSU alignment (3044 bp) inclusive of 20 specimens from New Zealand (Supplementary Table A.4.1) and 20 others from Genbank (Supplementary Table A.4.2). Sarcodia ciliata and S. marginata were used as outgroups for the $r b c \mathrm{~L}$ and LSU phylogenetic analyses following Saunders and Lemkuhl (2005). COI and LSU alignments were combined (3707 bp) for analyses (Supplementary Table A.5).

All data sets were analyzed using the following procedures. The $r b c \mathrm{~L}$ and $\mathrm{COI}$ protein-coding genes were partitioned by codon position for analyses. ML trees were constructed in RAxML v7.2.8 (Stamatakis 2006) using s GTR+G model, with a bootstrap analyses with 1000 iterations. MrBayes v3.2 (Ronquist and Huelsenbeck 2003) was used for BI analyses. Analyses consisted of two parallel runs with four Markov chains, run 
simultaneously for 3,000,000 generations sampled every 1000 generations with a $10 \%$ burnin.

\subsubsection{Species delimitation}

Multiple species delimitation approaches were used to evaluate the number of genetic species of Plocamium in the COI data set. The Automatic Barcode Gap Discovery (ABGD), General Mixed Yule Coalescent (GMYC), and Bayesian implementation of the Poisson Tree Processes (bPTP) methods were used.

The ABGD method was tested on the web interface available at http://wwwabi.snv.jussieu.fr/public/abgd/abgdweb/html. This method assessed the breaks in the distribution of genetic pair-wise distances, ranked these from smallest to largest, and then found the first statistically significant peak in the slope of values instead of using a fixed threshold (Puillandre et al. 2012). The test was run based on the predetermined model criteria: Kimura-2-parameters, an intraspecific variability $(P)$ between $0.001\left(P_{\min }\right)$ and 0.1 $\left(P_{\max }\right)$, a minimum gap width $(\mathrm{X})$ of 0.1 , and 50 screening steps.

GMYC required an ultrametric tree for analysis. The ultrametric tree was constructed with BEAST v1.8.2. Data files were first prepared in BEAUTi v1.8.2 with the following conditions: an uncorrelated lognormal relaxed clock, the site model GTR $+\mathrm{I}+\mathrm{G}$, set to a coalescent constant population, with Bayesian Markov chain Monte Carlo (MCMC) run for 30 million generations, sampling trees and parameters every 1000 generations. The estimated-effective sample size (ESS) was visualized in Tracer v1.6.0 (Rambaut et al. 2014). $25 \%$ of trees were then removed as burn-in, and a single summarized tree created with TreeAnnotator v.1.8.2 and checked with FigTree v1.4.2. GMYC analyses were performed on this summarized tree using the splits package (Ezard et al. 2009)(R-Forge, http://r-forge.rproject.org/projects/splits/) in R (R Development Core Team, http://www.R-project.org) 
under a single threshold model. The GMYC assigned branching events within species in two ways: speciation (at the species level) and coalescent (at the population level).

bPTP required a phylogenetic tree for analysis. A Bayesian tree was created in Mr. Bayes as specified above. This Bayesian tree was tested using the web interface available at http://species.h-its.org. Although the phylogenetic tree used for analysis in bPTP was not ultrametric as in GMYC, a comparison of the results is still acceptable (Zhang et al. 2013).

\subsubsection{Morphometric Analyses}

Morphometric measurements were conducted using scanned images of voucher specimens in the program ImgaeJ (Rasband 1997). The morphometry of 33 specimens belonging to each group of candidate species, previously delineated with the three genetic delimitation methods and two type specimens (P. cirrhosum and P. microcladioides) were analyzed (Supplementary Table A.6.). Group D and F were excluded from the morphometric analyses, as voucher specimens were not available for the respective sequence data. Diagnostic characters, used in previous studies (Yano et al. 2004) were selected: width of main axis (WMA), width of lowest basal ramuli (WLBR), length of lowest basal ramuli (LLBR), number of alternating series of ramuli (NASR), average number of ramuli per alternating series (ANRAS), curvature of basal ramuli (CBR) and serrations present or absent from basal ramuli (SERBR) (Fig. 1). All characters were averaged (mean) based upon 10 measurements per specimen one centimeter from the apical tip of each randomly selected branch. Multivariate and univariate analyses were conducted to test for differences in morphometric measurements between the previously determined genetic species. 


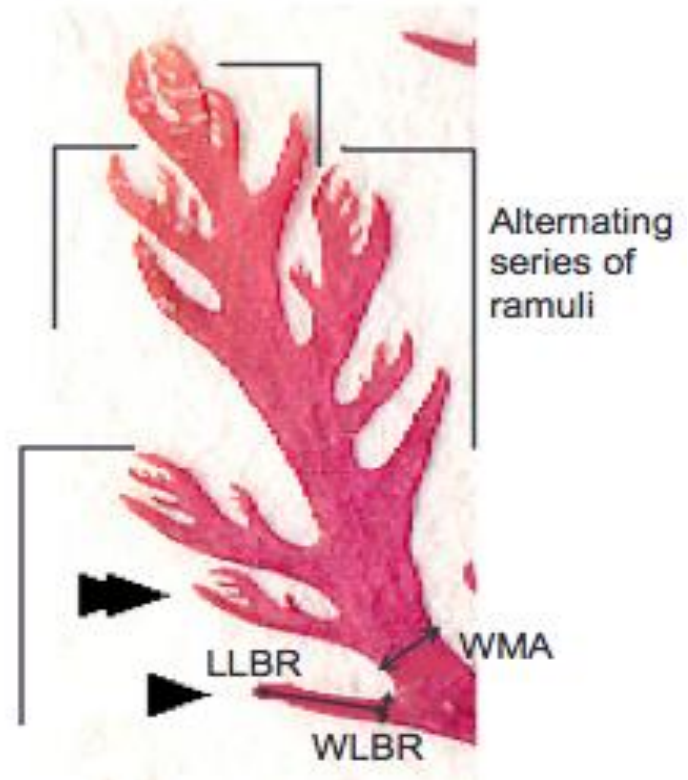

a.

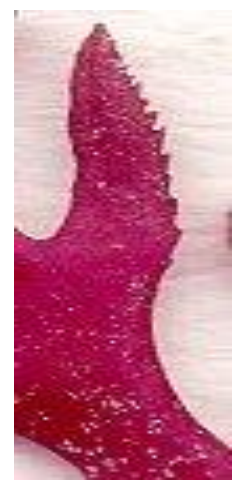

b.

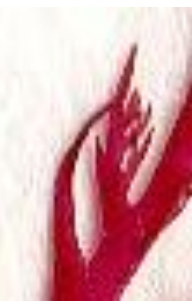

Adaxially Curving (1)

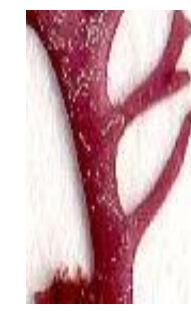

Slight

Adaxial

Curving (2)

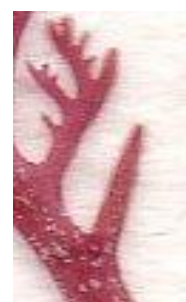

Linear (3)

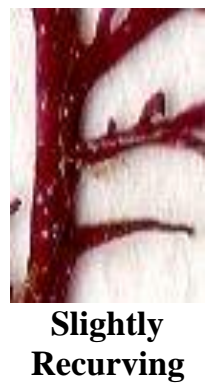

(4)

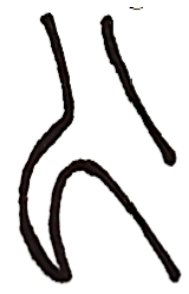

Strongly Recurving (5)

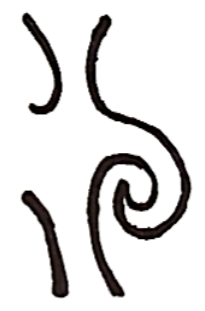

Coiling (6)

Fig. 1. a. Image of Plocamium thalli (A2, "candidate species" A) from one centimeter from the apical tip. The lines indicate where measurements were taken, the brackets highlight the alternating series of ramuli, the single arrowhead indicates the lowest basal ramulus, and the double arrowhead indicates the upper ramuli. Where the dimensions for length of lowest basal ramuli (LLBR), width of lowest basal ramuli (WLBR), and width of main axis (WMA) were taken is shown here. b. Shows (A6, "candidate species" E) a lowest basal ramuli with a serrated abaxial margin. c. Defines the six types of lowest basal ramuli curvature used and the ordinal number (1 to 6) associated with curvature type.

Multivariate analyses and subsequent univariate analyses of the morphometric data were performed in R. The "candidate species" delineated by the previous genetic analyses were added as a fixed factor to the matrix of morphological data. Principal Components Analysis (PCA), Discriminant Analysis (DA), and multivariate analyses of variance (MANOVA: Wilks' Lambda, Pillai's Trace, Hotelling-Lawley, and Roy’s Greatest Root) 
were conducted. Subsequent One-way ANOVA's were conducted for each variable and Tukey's test performed to verify the differences between means. The data was logtransformed to meet the assumption of normality and homogeneity of variances. A significance level of 0.05 was used.

\subsection{Results}

\subsubsection{Phylogenetic analyses and Species Delimitations}

The COI alignment was 663 bp long and contained 50 specimens and 23 Genbank sequences. Phylogenetic trees obtained from ML and BI analyses of the COI dataset were topologically congruent and only the Bayesian tree is shown (Fig. 2). This data set indicated that many of the New Zealand, plus some Australian samples, formed a clade, distinct from samples from other parts of the world, though this relationship was not supported. However, at least two of these candidate species groups from New Zealand (A and B) were not part of this clade. While many of the backbone relationships were not well supported, many clades of New Zealand samples had moderate to strong support. These supported clades often corresponded to genetic species delimitation groups (see below) (Fig. 2).

ABGD, GMYC, and bPTP were used for species delimitation based on the COI data set. The three methods resulted in different numbers of candidate species; ABGD yielded 11 species $(\mathrm{P}=0.001), 12$ with GMYC $\left(\mathrm{L}_{\mathrm{GMYC}}=519.67>\mathrm{L}_{0}=503.11, \mathrm{P}=0.01\right)$, and 16 species from bPTP (Fig.2). To reconcile these differences, candidate species were distinguished based on "majority rule" (i.e. if two or more of the methods agreed). All three species delimitation methods supported candidate species A, B, C, D, F, G, and H (Fig. 2.). ABGD and GMYC supported candidate species E and I (Fig. 2). GMYC and bPTP supported species J and K (Fig. 2). 


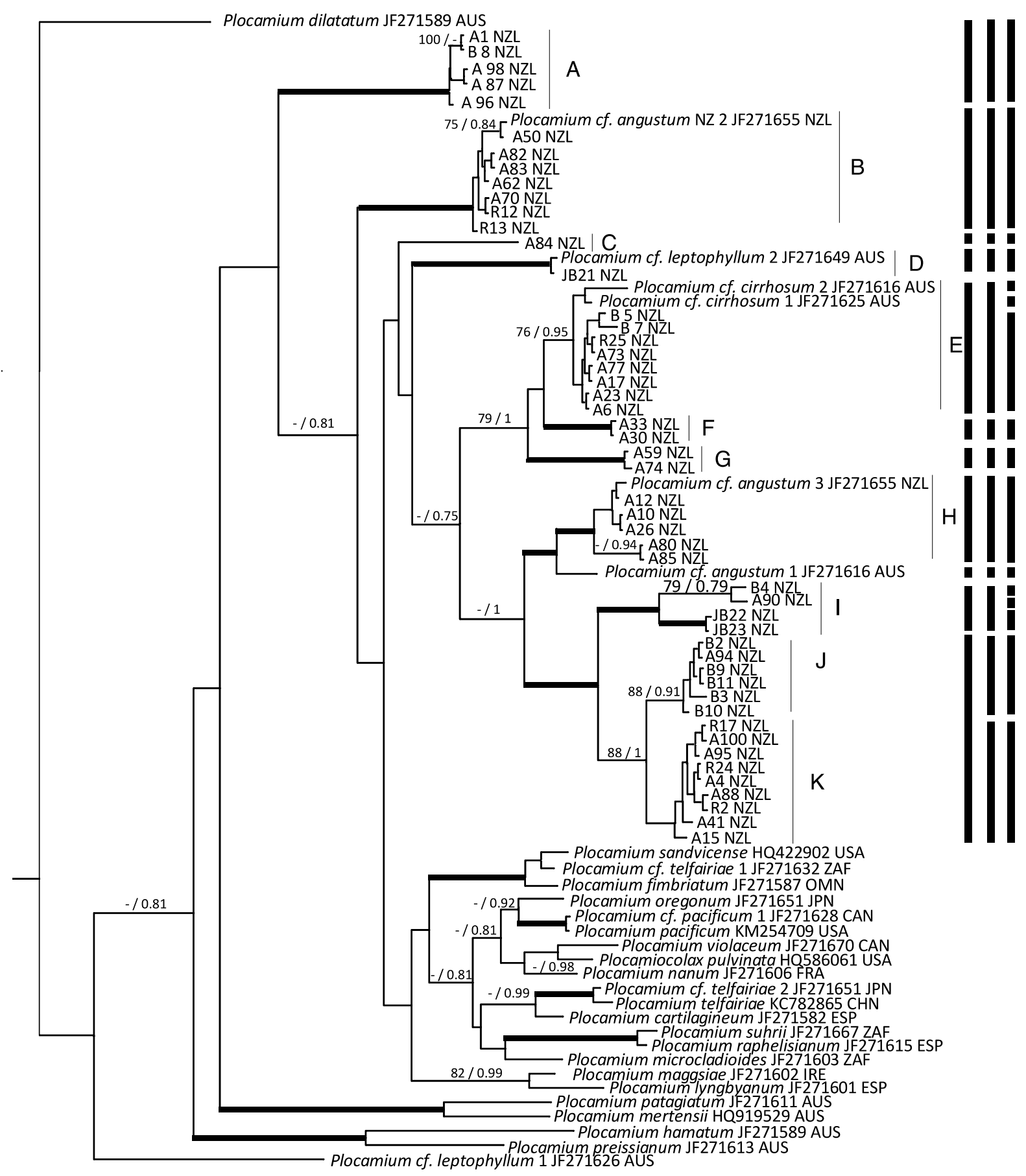

Fig. 2. Phylogenetic tree generated using Bayesian Inference inferred from partial COI sequences (showing BI > 0.70 and ML bootstrap values $>75 \%$ ). Bold branches indicate strongly supported branches (BI >0.98 and ML bootstraps > 95\%). Species delimitation methods based on ABGD, GMYC, and bPTP are indicated for New Zealand specimens, as well as labels (A to K) for candidate species groups. 
Individual LSU and $r b c \mathrm{~L}$ trees, along with combined LSU and COI trees were constructed in an attempt to add support to the backbone structure. The $r b c \mathrm{~L}$ alignment was 1083 bp long. The LSU alignment was 3044 bp long. The $r b c$ L (Supplementary Figure A.1) and LSU (Supplementary Fig. A.2) trees were not incongruent, but also yielded weak support. The $r b c \mathrm{~L}$ data set indicated that many of the New Zealand, plus a Chilean Genbank sequence and a Taiwanese Genbank sequence formed a clade distinct from samples from other parts of the world, though this relationship was not well supported. However some of the New Zealand clades did show moderate to strong support, for example groupings of candidate species E, F and G, and I, J, and K. The LSU data set also indicated New Zealand and some Australian samples monophyletic clades, but their backbone support was again weak. The data set showed there are some of the same species in Australia as in New Zealand. The combined analyses of COI and LSU (3707 bp) were conducted in an attempt to resolve the backbone structure (Fig. 3). Some candidate species did group with some support (e.g. E, F, G; and I, J, K; and moderate support for A, B, C). 


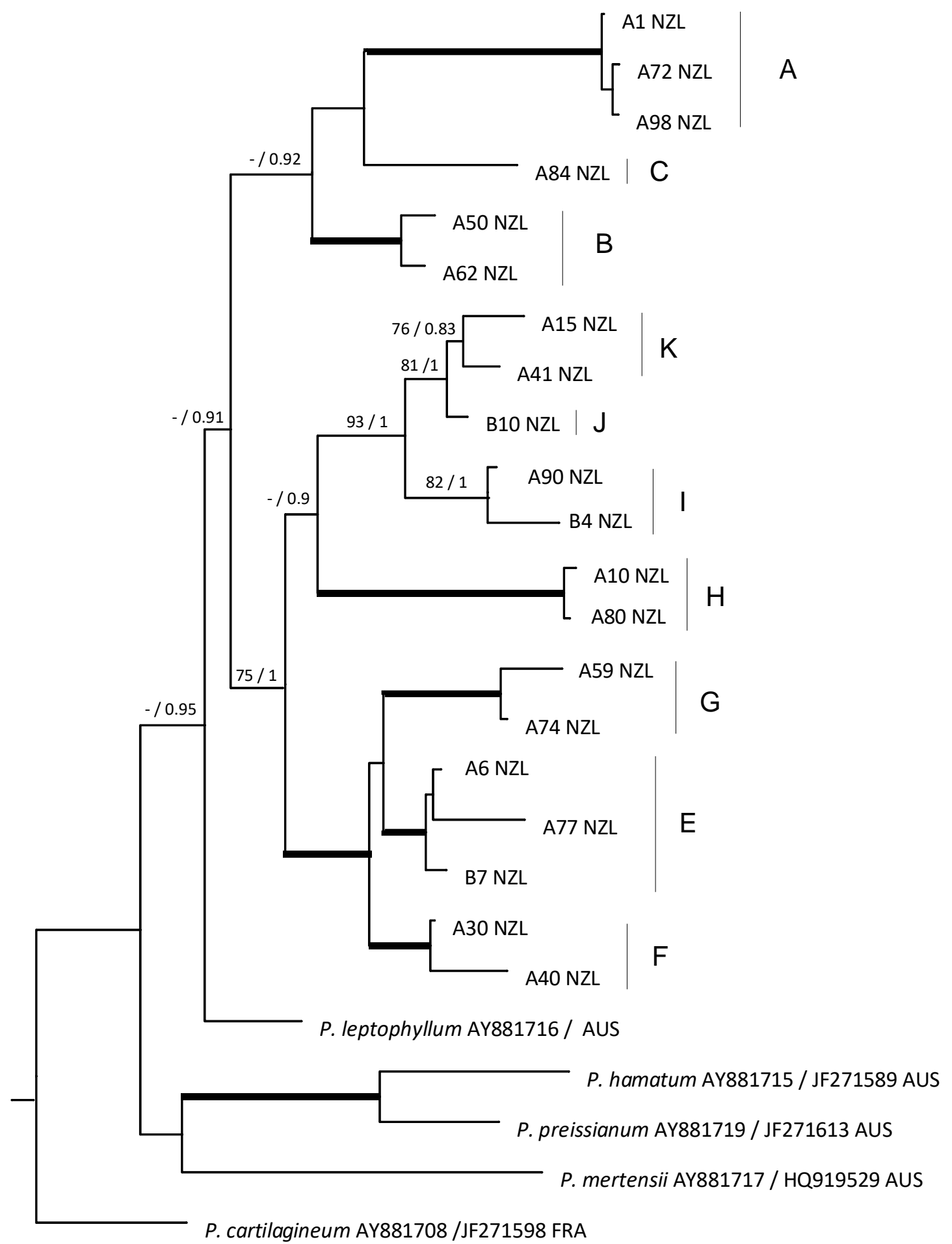

Fig. 3. Phylogenetic tree generated using Bayesian Inference inferred from combined partial COI sequences and LSU sequences (with BI > 0.70 and ML bootstrap values > 75\%). Bold branches indicate strongly supported branches (BI > 0.98 and ML bootstraps $>95 \%)$. Species delimitations from COI data are indicated for New Zealand candidate species groups (A to K). 


\subsubsection{Morphometric Analyses}

A morphological description of each of the seven reported species within New Zealand can be found within the General Introduction (Section 1.4.1) (Womersley 1971, South and Adams 1979, Adams 1994, Nelson 2013). Multivariate analyses of the morphometric data resulted in identification of mean differences between some the candidate species delimited by the molecular methods. Groups D and F were excluded from the morphometric analyses, as voucher specimens were not available for these samples. A summary of the measurements taken across genetic species in provided (Table 2).

When considering the chosen morphological characters, the first 2 principal components represent $55.1 \%$ and $21.2 \%$ of the morphological variability, approximately $76.3 \%$ of the total observed variability. The first component of the PCA (PC1) strongly separated candidate species E and K (Fig. 4). WMA, WLBR, LLBR and SERBR were the characters deemed most important (Fig. 4, Table TA.7). The second component (PC2) separated groups based on ANRAS and CBR (Fig. 4, Supplementary Table A.7).

The biplot of the PCA revealed certain candidate species did not occupy overlapping regions. The type specimen of $P$. microcladioides grouped separately from all other specimens, as did candidate species G. Although there was character overlap between candidate species $\mathrm{A}$ and $\mathrm{K}$, and $\mathrm{A}$ and $\mathrm{E}$, distinction between these species is still apparent. However, most candidate species clusters displayed partial or complete overlap. The type specimen for $P$. cirrhosum and candidate species $\mathbf{J}$ grouped with species E. The first quadrant contained species G, the left side of the graph (the second and third quadrats) contained most of the species (B, C, H, I, K, and 
P. microcladioides), E, J and the type of $P$. cirrhosum occupied the fourth quadrant, whilst species A was widespread between the second, third and fourth quadrants.

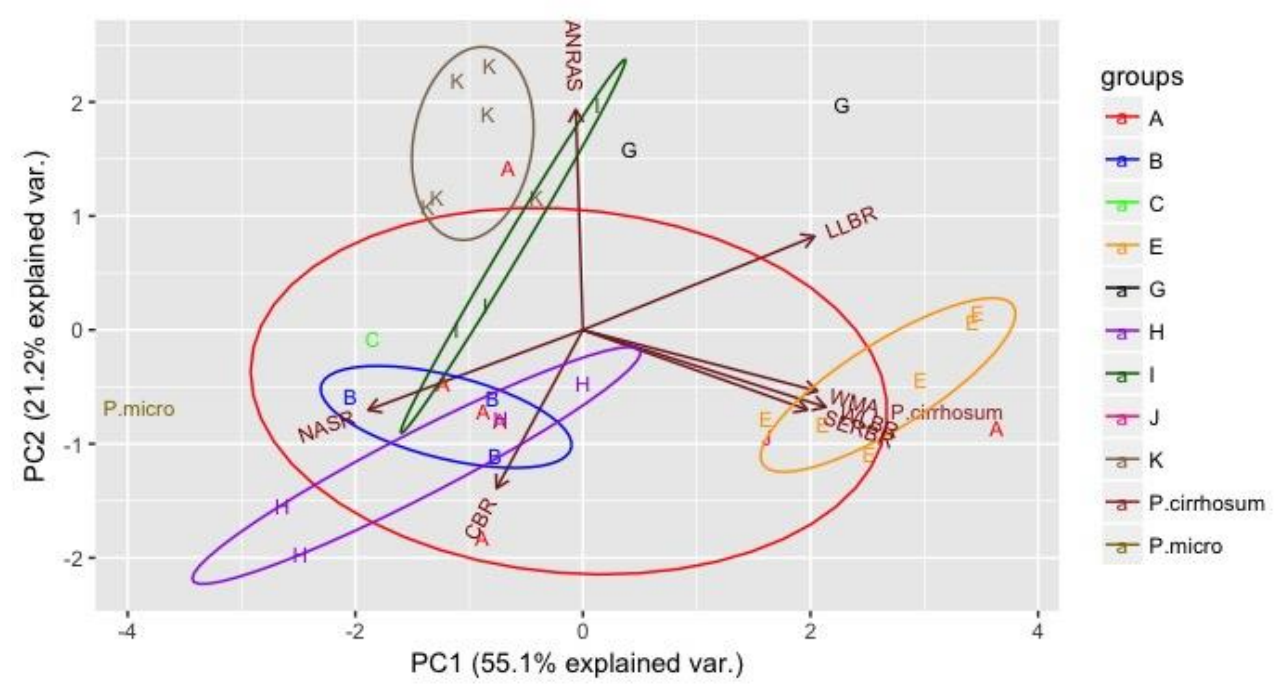

Fig. 4. The PCA bioplot showing the scores of the first two principal components of the PCA using 7 morphological characters of 9 candidate species groups of Plocamium occurring in New Zealand (A-J exclusive of $\mathrm{D}$ and $\mathrm{F}$ ) and the Type specimen for $P$. cirrhosum and $P$. microcladioides (P. micro). The first principal component (PC1) accounts for $55.1 \%$ of the explained variance (var.) and the second principal component (PC2) accounts for $21.2 \%$ of the explained variance.

The DA analysis showed strong evidence that the diagnostic characters chosen when considered conjointly indicated differences between species. The classification test was able to correctly discriminant 34 of the 35 specimens (97.14\% success) (Supplementary Table A.8), although the PCA biplot (Fig. 4) did not show obvious species separation for all candidate species. The misidentification was the grouping of a specimen from species group I into group K (Supplementary Table A.8).

The MANOVA results indicated significant differences between the “candidate species" previously delineated by genetic methods across all multivariate tests (Supplementary Table A.9). The one-way MANOVA showed strong evidence of a significant effect, and will help protect the results from Type 1 errors (detecting a 
significant effect when one is not truly present or a false positive), subsequent univariate and post-hoc analyses were conducted for each of the response variables. The One-way ANOVA revealed statistically significant differences between at least two of the "candidate species" A, B, C, E, G, H, I, J, K, and the type of $P$. cirrhosum and $P$. microcladioides when considering each of the selected diagnostic characters individually (Supplementary Table A.10, Fig. 5).

Post-hoc analyses (Tukey's Tests) revealed the significant morphometric parameters that allowed us to separate group pairs morphologically, which were sister lineages in the phylogenetic trees (Fig. 2). Tukey's Tests revealed no mean differences of any of the variables between the Type Specimen of P. cirrhosum and “candidate species” E or J (Supplementary Table. A.11-A.17). Where previous delimitation methods disagreed (GMYC separated species $\mathrm{J}$ and $\mathrm{K}$, when ABGD grouped them), morphological analyses revealed significant differences in WMA and SERBR between J and K. DA analysis classification test misidentified species I as K, the results of the post-hoc test revealed no significant differences between any of the measured characters.

\subsubsection{Species Name Assignments}

Species delimitation keys were used in an attempt to assign candidate genetic species groups (excluding D and F) to recognized Plocamium species (Adams 1994).

Species E: Comparison of morphometric analyses with the type specimen of P. cirrhosum indicated no significant differences across any of the characters analyses. When following the original descriptions and species keys, specimen of candidate species E are identified as $P$. cirrhosum. All three species delimitation 
methods separate this species from other lineages (Fig. 2). Based on this evidence candidate species E will be assigned to P. cirrhosum.

Species G: Based on comparisons across species keys, and having taken into account the results of the morphometric analyses, it would seem that candidate species G should be considered $P$. cartilagineum. However, all three species delimitation methods differentiate species $G$ from other lineages, including Northern European isolates of $P$. cartilagineum from Genbank, which indicates it is not $P$. cartilagineum as the type is from Northern Europe.

Species A, B, C: Comparison across all morphological characters indicated no significant differences for any of the test variables between species A, B and C. Molecularly, all delimitation methods agreed on the partitioning of the three species, and there is some, but weak, support indicating these three species form a clade. Given the observed data, following species keys and species descriptions, this clade should tentatively be recognized as $P$. angustum, consisting of three cryptic species.

Species $\mathrm{H}$ : When considering all the above morphological criteria, species $\mathrm{H}$ also matched $P$. angustum.

Species I, J and K: Morphologically species groups K and I showed no significant differences across any of the morphological characters. However, species $\mathbf{J}$ differed significantly from the groups based on width of main axes and serrations. Phylogenetic analyses of COI, $r b c \mathrm{~L}$, LSU, and combined data sets showed strong support within the New Zealand clade for grouping genetic species I, J and K. The four samples compromising species I, were distinguished with strong support in the $\mathrm{COI}$ analysis. The six specimens comprising species group $\mathrm{J}$ and the nine of group $\mathrm{K}$, were distinguished with weak ML support but strong BI support. J and K were differentiated with species delimitation methods bPTP and GMYC, but splitting 
between these two groups was not supported by AGBD. Species keys and descriptions also indicate species I, J, and K match P. angustum. 

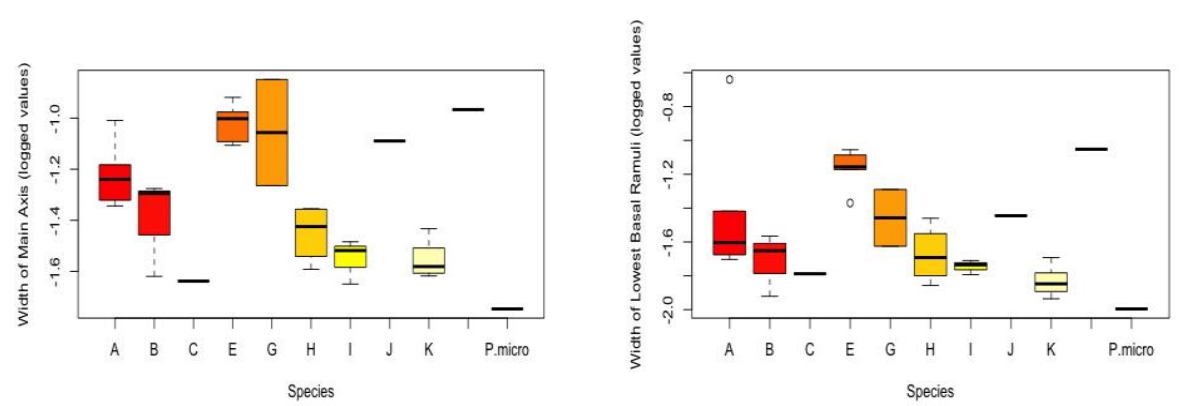

a.
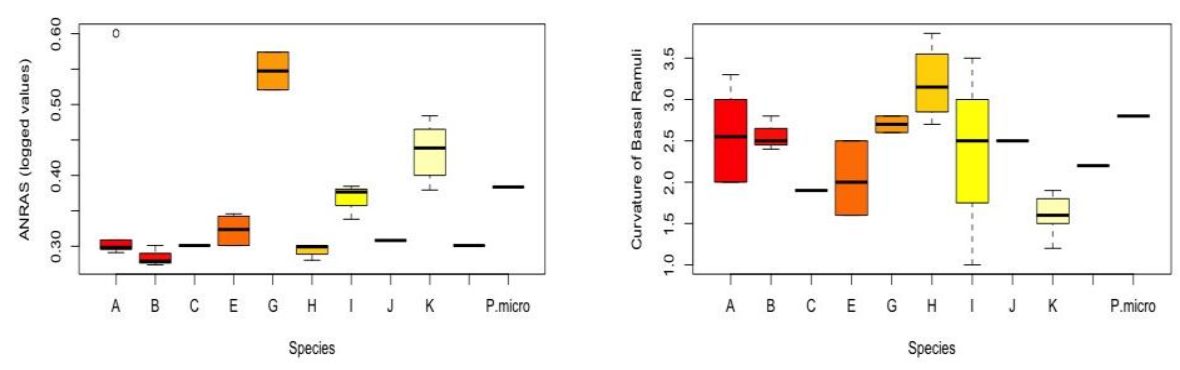

e.

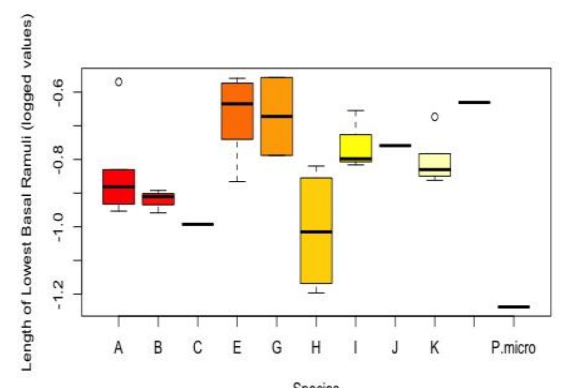

Species

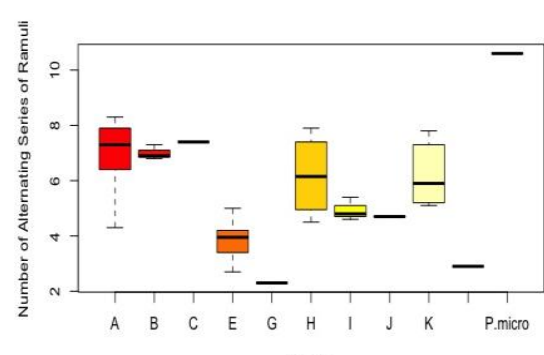

Species

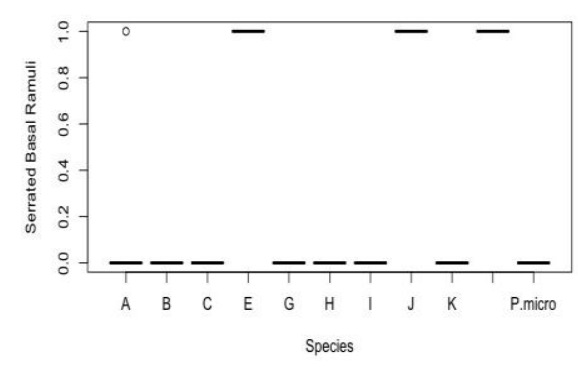

f.

g.

Fig. 5. Box plots of the seven diagnostic characters obtained from measurements of the nine candidate species and two type specimens ( $P$. cirrhosum (the blank space) and $P$. microcladioides (P. micro)) logged values, when used, indicated. a. Character "Width of main axis" (WMA). b. Character "Width of lowest basal ramuli" (WLBR). c.

Character "Length of lowest basal ramuli" (LLBR). d. Character "Number of alternating series of ramuli" (NASR). e. Character "Average number of ramuli per alternating series" (ANRAS). f. Character "Curvature of basal ramuli” (CBR). g. Character "Serration of basal ramuli" (SERBR). Boxes represent 75th percentiles, horizontal lines signify 5th and 95th percentiles, bold bars denote mean values, and empty circles indicate outliers. 
Table 2. Summary of the resulting morphometric characters of the New Zealand Plocamium included in this morphometric study.

\begin{tabular}{|c|c|c|c|c|c|c|c|}
\hline Plocamium Species & $\begin{array}{l}\text { Ave. (Min. - } \\
\text { Max.) Width of } \\
\text { Main Axis }(\mu \mathrm{m})\end{array}$ & $\begin{array}{l}\text { Ave. (Min. - } \\
\text { Max.) Width of } \\
\text { Lowest Basal } \\
\text { Ramuli }(\mu \mathrm{m})\end{array}$ & $\begin{array}{l}\text { Ave. (Min. - } \\
\text { Max.) Length of } \\
\text { Lowest Basal } \\
\text { Ramuli (mm) }\end{array}$ & $\begin{array}{l}\text { No. Alternating } \\
\text { Series of Ramuli }\end{array}$ & $\begin{array}{l}\text { No. Ramuli Per } \\
\text { Alternating } \\
\text { Series }\end{array}$ & $\begin{array}{l}\text { Curvature of } \\
\text { Basal Ramuli } \\
(1-6)\end{array}$ & $\begin{array}{l}\text { Serration of } \\
\text { Basal Ramuli }\end{array}$ \\
\hline $\mathrm{A}$ & $620(300-1400)$ & $597(110-1200)$ & $1.5(0.1-2)$ & $5-11$ & 2 & $3(1-5)$ & Only Rarely \\
\hline $\mathrm{B}$ & $375(130-720)$ & $195(80-400)$ & $1.2(0.75-1.73)$ & $4-9$ & 2 & $3(1-3)$ & No \\
\hline $\mathrm{C}$ & $230(170-290)$ & $163(80-280)$ & $1(0.6-1.8)$ & $6-9$ & 2 & $2(1-2)$ & No \\
\hline $\mathrm{E}$ & $\begin{array}{c}1000(420- \\
1630)\end{array}$ & $750(420-1420)$ & $2.4(0.7-3.7)$ & $2-6$ & $2-3$ & $2(1-3)$ & Yes \\
\hline $\mathrm{G}$ & $600(330-1100)$ & $375(60-850)$ & $2.2(0.6-4)$ & $2-3$ & $3-4$ & $3(1-4)$ & No \\
\hline $\mathrm{H}$ & $340(80-570)$ & $220(40-420)$ & $1(0.3-2.2)$ & $3-12$ & 2 & $3(1-5)$ & No \\
\hline I & $250(110-400)$ & $180(60-340)$ & $1.78(0.8-2.9)$ & $3-8$ & $2-3$ & $1(1-5)$ & No \\
\hline $\mathrm{J}$ & $810(400-1300)$ & $360(200-500)$ & $1.75(0.9-2.6)$ & $3-7$ & 2 & $2(1-4)$ & Yes \\
\hline $\mathrm{K}$ & $305(80-530)$ & $170(60-290)$ & $1.9(0.8-2.9)$ & $3-12$ & $2-3$ & $1(1-3)$ & No \\
\hline P. cirrhosum* & $\begin{array}{c}1080(750- \\
1500)\end{array}$ & $890(500-1200)$ & $2.3(1.9-3.1)$ & $2-4$ & 2 & 2 & Yes \\
\hline $\begin{array}{l}P . \\
\text { microcladioides } *\end{array}$ & $180(140-290)$ & $100(60-130)$ & $0.6(0.4-0.8)$ & $8-13$ & $2-3$ & $3(2-4)$ & No \\
\hline
\end{tabular}




\subsection{Discussion}

This is the first study to use molecular-assisted alpha taxonomy to delineate species diversity of Plocamium within New Zealand. Currently, there are seven reported species within New Zealand (South and Adams 1979, Adams 1994, Nelson 2013). Molecular assessment of this diversity revealed previous species circumscriptions based on morphology were underestimated. Morphometric analyses indicated that these species could be identified morphologically to some extent when multiple measurements of multiple characters were taken into account.

\subsubsection{Species Delimitation and Morphometrics}

The attempt to use three different species delimitations methods (each with different algorithmic techniques) on the COI dataset indicated results that support the occurrence of at least 11 genetic species of Plocamium within New Zealand. This finding of increased species diversity compared to expected levels is not uncommon and has been seen in other algal species (Zuccarello and West 2003, Payo et al. 2013, Muangmai et al. 2014, Díaz-Martínez et al. 2016). Similar findings of unexpected genetic diversity in seemingly morphologically identical species of Plocamium were also found in northern Europe (Saunders and Lehmkuhl 2005, Cremades et al. 2011).

However, there were minor disagreements observed between genetic delimitation methods, as found in putative species I and between species $\mathrm{J}$ and $\mathrm{K}$. These disagreements between species-delimitation methods are most likely due to the different algorithmic techniques specific to each analysis. The ABGD method differentiates species dependent on within and between species genetic divergence (Puillandre et al. 2012). This would be considered a more conservative approach when compared to GMYC and bPTP. The GMYC and bPTP methods infer putative 
species based on species boundaries determined from phylogenetic trees. Species are delimited from the GMYC model based on the significant changes in the pace of branching events to determine transition points, meaning it is a time based model (Zhang et al. 2013). Unlike the GMYC model the bPTP model is not based on time but on the direct number of substitutions, functioning on the basic assumption that substitution rates between species will be higher than within (Zhang et al. 2013). This means that these models can overestimate based on singletons, low sample numbers, and/or unbalanced sampling (Zhang et al. 2013, Muangmai et al. 2014), which may be the case here.

Plocamium in New Zealand has been defined based on the morphological species concept. While this concept holds true for some species, there are others that display analogous morphological traits. Based on the results of this study, when using morphometric techniques it appears that morphological diversity does, to some extent, reflect genetic differentiation. While there were no clear diagnostic characters present that could singularly identify species (i.e. the set of characters currently used for morphological identifications is not sufficient to distinguish the species), morphometric analyses revealed that morphological differences between putative species do exist. The most useful characters for species identification were: WMA, WLBR, LLBR, and SERBR; consistent with the findings of other studies (Yano et al. 2004, Cremades et al. 2011). Other algal genera, e.g. Halimeda (Verbruggen et al. 2005) and Padina (Díaz-Martínez et al. 2016), have shown that multiple measurements across a set of multiple characters allows for differentiation of alga that could previous only be separated genetically.

Previous taxonomic studies, based on morphology have underestimated species diversity in this genus. Although there were inconsistencies across 
delimitation methods and identification based on single character morphology could not be achieved, the recognition of these candidate genetic species is the beginning to uncover the true species diversity of Plocamium within New Zealand. If increased sampling occurs and the species delimitations are sustained, further investigations into morphological, reproductive, physiological, chemical and geographical differences are justified.

\subsubsection{Application of Species Names and What Else is Needed}

Applying names to these lineages is difficult at present. First it should be noted, that these species identifications are to be taken with caution, as reproductive tissues were not present on most specimens, and have not been considered in this study. Also names were not assigned to specimen in putative species groups D and $\mathrm{F}$ as there were no morphological data for these specimens. Names applied to singleton putative species and specimen that have only one morphological specimen $(\mathrm{C}, \mathrm{J})$ should be viewed with caution as well. Only one (species E) of putative species could be confidently associated with a name across all of the above criteria (Plocamium cirrhosum). Given the current available species keys and descriptions, and using the morphological and molecular results from this study, for the recognized New Zealand Plocamium, the specimens were given tentative names where appropriate. P. hookeri, P. hamatum, P. leptopyllum, and P. microcladiodes were not found through MAAT analyses.

Given that the type specimen of $P$. cirrhosum is from Dusky Sounds (Fiordland, Southland, New Zealand), morphologically congruent with the specimens from candidate species E, the application of this name does seem appropriate to this 
lineage. Sequence data (A77) from Southland (near the type locality) supports this as well.

Based on morphological conclusions, species $\mathrm{G}$ was tentatively assigned through species keys as $P$. cartilagineum. However, molecular data did not confirm this, clearly separating it from northern European (type locality) isolates. Although extensive work has been done on this species in other parts of the world (Yano et al. 2004, Saunders and Lehmkuhl 2005, Cremades et al. 2011), there is still confusion about its taxonomic status. It is often divided into cryptic (genetic) species, or identified as new species morphologically (Saunders and Lehmkuhl 2005, Cremades et al. 2011). This species and the taxonomic uncertainties associated with it makes molecular characterization key for clarification of the correct name.

Species A, B and C; species $\mathrm{H}$; and species I, J, and $\mathrm{K}$ are all recognized as $P$. angustum. The results of the Tukeys' tests revealed some between group disagreements amongst these three clades. Morphological differences were found when multiple measures of multiple characters were analyzed, indicating possible cryptic and pseudo-cryptic species. Species A differed in WMA when compared with species I and K. Species H was distinguished from species $\mathrm{K}$ when ANASR and CBR were considered. These morphological differences indicate that these seemingly cryptic species might actually be species in a morphological sense as well. The COI data in conjunction with the morphological evidence indicate that the wide application of the name $P$. angustum might not be appropriate, plus various Genbank sequences given the name are found in different New Zealand clades. Strict morphological analyses and/ or sequence data from the type or material from the type locality (Australia), is necessary for clarification of the correct application of the name. Then it can be determine which New Zealand lineage fits the type. 
The molecular and morphometric analyses have demonstrated that current morphological characters, used to delineate Plocamium in New Zealand, are not taxonomically informative at the species level. To create more robust species identifications and delimitations a shift towards combined molecular and morphological methods needs to occur. Chemical analysis of intracellular acidity (Yano et al. 2004), investigation into the reproductive potential between species (Zuccarello and West 2003), physiological differences (Muangmai et al. 2014), and an attempt at a revision of morphology of the type specimens (or samples from the type localities) (Aguirre and Braga 1998) and molecular characterization of types (Hughey and Gabrielson 2012) are necessary to ensure proper names are being used.

\subsubsection{New Zealand Plocamium and Its Relationship with Species in Other Parts of the} World

The taxonomy of Plocamium worldwide is problematic (Lehmkuhl 2003, Yano et al. 2004, Cremades et al. 2011). Phylogenetic analyses obtained from the markers suggest the possible monophyly of New Zealand species $(\mathrm{C}-\mathrm{K})$. The diversification of these species seems to have occurred within New Zealand. High diversity, speciation and endemism have been reported across many organisms within New Zealand (Broom et al. 2004, Gordon et al. 2010, Muangmai et al. 2014, Nelson et al. 2015). The possible cryptic speciation of Plocamium within some of the New Zealand clades can possibly be attributed to New Zealand's split from Australia and Antarctica, and its high number of associated islands (Gordon et al. 2010). A mix of warmer more saline tropical and sub-tropical waters brought down from Australia and cooler less saline subantarctic waters brought up from the subantarctic islands and the diverse geography and topography of New Zealand's coast promotes these patterns as 
well (Parsons 1985, Gordon et al. 2010). New Zealand's long isolation ( $~ 80$ million years), ocean currents and diverse coastal and seafloors habitats support these high levels of diversity, speciation, and endemism.

The results of the molecular analyses also indicate that New Zealand species may share relationships with Plocamium species in Australia, Chile, and Taiwan. This trend in diversity is not uncommon (Parsons 1985, Guillemin et al. 2014). Southern hemisphere (sub-tropical) links between algal species has been proposed in previous studies (Fraser et al. 2009, Muangmai et al. 2014). It is hypothesized that links between southern hemisphere algal species such as Gracillaria chilensis (Guillemin et al. 2014), Carphophyllum mascholocarpum (Buchanan 2005), and Bostrychia (Muangmai et al. 2014) could have risen from factors occurring during the Last Glacial Maximum (LGM). Other hypotheses suggest Australian and New Zealand species have Gondwanan origins (Costello et al. 2010).

While some of the Plocamium species in New Zealand were separated from other species from other parts of the world, the relationship between species is unclear. Analyses of single markers nor conjoint markers resolved these relationships. Additional sampling of these species from a broader range of locations, assessing other molecular markers and further analyses to estimate the divergence time for the species, would help resolve these relationships.

\subsubsection{Conclusion}

This study’s molecular-assisted taxonomic approach provides insights into the taxonomy of Plocamium in New Zealand. Although the identification of at least eleven genetic and possibly morphometrically distinct species has been acknowledge where there were only seven, a final understanding of species diversity in New 
Zealand is far from complete. It is evident based on currently recognized species keys and diagnostic characters that New Zealand Plocamium species are not easily distinguishable but can to a certain degree be when analyzing multiple measures across multiple characters. Future study into the Plocamium of New Zealand will allow for a deeper understanding of its biodiversity, endemism, and evolutionary relationships with other regions around the world. 


\section{General Discussion}

This study has three main findings: 1] the delimitation of additional Plocamium species within New Zealand; 2] evidence of morphology reflecting genetic diversity to a certain degree (morphometrics may be the only way to distinguish between certain species versus single character analyses); 3] the evolutionary relationships tentatively grouping New Zealand species with Australia, Chile, and Taiwan.

\subsection{DNA Barcoding and MAAT}

This study shows that prior to molecular analyses, specimens of Plocamium that lack reproductive structures could not be convincingly identified at the species level based on species delimitation keys, which do not take into account multiple measurements of vegetative characters. Using traditional morphological characters to accurately identify specimens to the species level can be difficult and seemingly impossible for many red algal species (Saunders 2005, Leliaert et al. 2014). Similar studies have identified cryptic and pseudo-cryptic speciation in northern Europe (Saunders and Lehmkuhl 2005, Cremades et al. 2011) and Japan (Yano et al. 2004). Molecular techniques are used as a solution to taxonomic problems and to reveal hidden diversity.

DNA barcoding, the use of various species delimitation methods, and MAAT for species identification allows for accurate identification, reveals true diversity between morphologically similar species despite their life stage, and may uncover new species (Verbruggen et al. 2005, Cianciola et al. 2010, Leliaert et al. 2014). DNA barcoding is a method intended to deliver fast, accurate, automatable species identifications by using gene regions as species tags (Hubert and Hanner 2015). 
However, this requires supported taxonomy so that samples can be identified to an already named and cataloged species (Hubert and Hanner 2015).

When sequence data reveals genetic differentiation, cryptic or pseudo-cryptic (species that have not had a specific distinguishing diagnostic trait or set of traits recognized) species, MAAT and/or morphometric analyses that take into account multiple measurements of multiple characters can ease the difficulty and increase the reliability of algal identifications (Verbruggen et al. 2005, Saunders 2008, Cianciola et al. 2010). MAAT, unlike DNA Barcoding, works towards determining species based on sequence data that have established a priori genetic species groups. Combining and comparing statistical analyses of morphological characters with species delimitation and genetic data helps to create more robust species identifications, descriptions and taxonomic conclusions.

\subsection{Resolving Taxonomic Relationships}

Plocamium is a cosmopolitan genus and its taxonomy is a problem worldwide (Yano et al. 2004, Saunders and Lehmkuhl 2005, Cremades et al. 2011). The phylogenetic analyses have revealed some Plocamium species in New Zealand may share relationships with Australian, South American, and Taiwanese samples, separating it from most other Northern Hemisphere and Southern Hemisphere lineages. This separation of Northern and Southern Hemisphere species (at least New Zealand species) indicated within the study means that some names may not hold due to the apparent differentiation and monophyly of some New Zealand and other Southern species, as seen in Asparogopsis spp. (Dijoux et al. 2014). However the relationships in this study were not clear. 
To resolve these relationships with other parts of the world, there must be future integrative approaches applied, as here. Additional sampling of Plocamium is needed; this includes collecting additional specimens from areas that have already been sampled and collecting samples from new locations (e.g. Australia, South America, other Indo-Pacific regions) where species may be distributed. In general estimation of marine species richness is dependent on sampling effort (Costello et al. 2010, Dijoux et al. 2014). Given the worldwide distribution of Plocamium these sampling efforts will be necessary to clarify the biodiversity and geographic distribution pattern of these algae.

A wider and more extensive sampling regime needed and these samples must be vouchered and sequenced with multiple markers then catalogued for future study. Once catalogued (e.g. Genbank), these regional sequences should then concatenated and analyzed. Increased sample sizes, sequencing multiple markers, and application of morphometric analyses considering multiple measures of multiple characters for respective voucher specimens hopefully elucidate these relationships, creating stronger support for species relationships (Verbruggen et al. 2005, Cianciola et al. 2010, Costello et al. 2010, De Clerck et al. 2013, Nelson et al. 2013, Dijoux et al. 2014).

However, for proper species names to be applied and new species identified, type specimens must first be stringently morphologically analyzed and sequenced. Names of species are based on type specimen and are crucial comparative material for taxonomic investigations (McNeill et al. 2006). Multiple studies have shown that extraction and amplification of nuclear and plastid DNA from old (some dating back to the early 1900's) algal herbarium material can be isolated in practical and reproducible ways (Hughey et al. 2001, Hughey and Gabrielson 2012). Other studies 
highlight the importance of re-documentation of type material, focused on identification of diagnostic characters different from those used in modern taxonomy (Aguirre and Braga 1998, Iryu et al. 2009). To further resolve species relationships of Plocamium within New Zealand and around the world, attempts at type sequencing and reconsideration of the morphological characters associated with its modern taxonomy are a must. As shown in this study (P. angustum), it is possible to morphologically differentiate between species that are identified as the same species based on current species keys.

Using a combination of morphological and genetic analyses is not the only way to delineate species. Chemical analyses are also used within algal species as a way to provide species identifications (Naylor et al. 1983, Brondz and Olsen 1986, Amsler 2008, Maschek and Baker 2008). The pH measurements of Plocamium cell sap was investigated in Japan, and were considered useful in resolving species relationships (Yano et al. 2004). Assessing whether algal species are reproductively compatible is another possible way to resolve species delimitation problems (Zuccarello and West 2003). Studies on other algal studies reveal reproductive incompatibility between species complexes (e.g. Bostrychia spp.), suggesting that some cryptic and pseudo-cryptic species could be considered species under the biological species concept as well (Zuccarello and West 2003, Muangmai 2015). Investigation into the hybridization abilities of Plocamium species may be beneficial to further indicate species boundaries. 


\subsection{Conclusion}

Plocamium within New Zealand and around the world have traditionally been defined based on morphology (the morphological species concept). This has been problematic due to the significant and overlapping morphology associated with this taxa. Not only does morphological continuity present a challenge for species identifications within Plocamium, this holds across other red algal taxa as well. In an attempt to address these underlying issues, a molecular-assisted approach to taxonomy was used. This studies use of molecular analyses of COI, $r b c \mathrm{~L}, \mathrm{LSU}$, and combined data sets provide the first molecular evidence that Plocamium diversity has been underestimated in New Zealand. To investigate the genetic diversity, further morphometric analyses of multiple measures of multiple characters from a wide range of specimens collected throughout New Zealand were conducted. These results indicated that the eleven genetic species revealed in this study could be distinguished morphologically when multiple measures of multiple characters were considered. However, using current delimitation keys only allows us to identify three morphological variants within the study It is evident based on currently recognized species keys and diagnostic characters that Plocamium in New Zealand is not clearly distinguishable. This study showed the most useful characters for morphologically differentiating species were WMA, WLBR, ANASR, and SERBR (when multiple measures were taken). This set of characters may aid in field-identifications, however there is still more investigation that needs to be done, specifically incorporating reproductive structures into analyses.

Future studies to create more robust species identifications and delimitations need to occur. Further morphological analyses, molecular analyses, chemical analysis of intracellular acidity (Yano et al. 2004), investigation into the reproductive potential 
between species (Zuccarello and West 2003), physiological differences (Muangmai et al. 2014), and an attempt at a revision of morphology of the type specimens (or samples from the type localities) (Aguirre and Braga 1998) and molecular characterization of types (Hughey and Gabrielson 2012) are necessary to ensure proper names are being used. These studies will benefit New Zealand and aid in understanding its biodiversity, endemism, and evolutionary relationships with other parts of the world. 


\section{References}

ADAMS, D.C., RoHLF, F.J. \& SLICE, D.E. 2004. Geometric morphometrics: ten years of progress following the 'revolution'. Italian Journal of Zoology 71: 5-16.

ADAmS, N.M. 1994. Seaweeds of New Zealand. Canterbury University Press.

Afolayan, A.F., Mann, M.G., Lategan, C.A., Smith, P.J., Bolton, J.J. \& Beukes, D.R. 2009. Antiplasmodial halogenated monoterpenes from the marine red alga Plocamium cornutum. Phytochemistry 70: 597-600.

AGARDH, C. 1824. Synopsis Algarum. Literis Berlingaris. Pt XVI. Lundae.

AGARDH, C.A. 1817. Synopsis algarum Scandinaviae: adjecta dispositione universali algarum. ex officina Berlingiana.

AGARDH, J.G. 1841. In historiam algarum symbolae (Continuatio prima.).

AgARDH, J.G. 1842. Algae maris Mediterranei et Adriatici (Marine algae from Mediterranean and Adriatic Sea). Fortin. Masson et C. ie, Paris. pp. X.

AGARDH, J.G. 1876. Epicris systematis floridearum. O. Weigel.

AGUIRRE, J. \& BRAGA, J. 1998. Redescription of Lemoine's (1939) types of coralline algal species from Algeria. Palaeontology 41: 489-508.

AMSLER, C.D. 2008. Algal chemical ecology. Springer.

BJÖRKLUnd, M., SEMESI, A., MohAMmed, S. \& BJÖRK, M. 1995. Coralline algae, important coral-reef builders threatened by pollution.

Bookstein, F.L., Chernoff, B., Elder, R.L., Humphries, J.M., SMith, G.R. \& STRAUSS, R.E. 1985. Morphometrics in evolutionary biology: the geometry of size and shape change, with examples from fishes.

BORNET, J.B.E. \& THURET, G.A. 1867. Recherches sur la fécondation des Floridées. Victor Masson et Fils.

BRONDZ, I. \& OLSEN, I. 1986. Chemotaxonomy at a crossroads?: Gas chromatographic analyses of a single colony from the bacterium Haemophilus aphrophilus. Journal of Chromatography B: Biomedical Sciences and Applications 374: 119-124.

Broom, J., FARr, T. \& Nelson, W. 2004. Phylogeny of the Bangia flora of New Zealand suggests a southern origin for Porphyra and Bangia (Bangiales, Rhodophyta). Molecular Phylogenetics and Evolution 31: 1197-1207.

BUCHANAN, J. 2005. The crustose brown algae of New Zealand: a taxonomic study.

Chapin III, F.S., ZAVAlETA, E.S., Eviner, V.T., NAYlor, R.L., VitouseK, P.M., REYNOLDS, H.L., HoOPER, D.U., LAVOrEl, S., SAla, O.E. \& Hobbie, S.E. 2000. Consequences of changing biodiversity. Nature 405: 234-242.

Cianciola, E.N., Popolizio, T.R., Schneider, C.W. \& Lane, C.E. 2010. Using molecular-assisted alpha taxonomy to better understand red algal biodiversity in Bermuda. Diversity 2: 946-958.

Cole, K.M. \& ShEATH, R.G. 1990. Biology of the red algae. Cambridge University Press.

Costello, M.J., Coll, M., Danovaro, R., Halpin, P., Ojaveer, H. \& Miloslavich, P. 2010. A census of marine biodiversity knowledge, resources, and future challenges. PloS one 5: e12110.

Cremades, J., Barreiro, R., Maneiro, I. \& Saunders, G.W. 2011. A new taxonomic interpretation of the type of Plocamium cartilagineum (Plocamiales, Florideophyceae) and its consequences. European journal of phycology 46: $125-142$.

DAYRAT, B. 2005. Towards integrative taxonomy. Biological journal of the Linnean society 85: 407-415. 
De Clerck, O., Guiry, M.D., Leliaert, F., SAmyn, Y. \& Verbruggen, H. 2013. Algal taxonomy: a road to nowhere? Journal of Phycology 49: 215-225.

DE QUEIROZ, K. 2007. Species concepts and species delimitation. Systematic biology 56: $879-886$.

Díaz-Martínez, S., Zuccarello, G.C., Chávez, G.A.S., Pedroche, F.F. \& AvilaORTIZ, A.G. 2016. Species of Padina (Dictyotales, Phaeophyceae) in tropical Mexican waters based on molecular-assisted taxonomy. Phycologia 55: 673687.

DiJOUX, L., ViARD, F. \& PAYRI, C. 2014. The more we search, the more we find: discovery of a new lineage and a new species complex in the genus Asparagopsis. PLoS One 9: e103826.

DiKOw, T., MEIER, R., VAIDYA, G.G. \& LONDT, J.G.H. 2009. Biodiversity research based on taxonomic revisions-a tale of unrealized opportunities. Diptera Diversity: Status, Challenges and Tools. Brill Academic Publishers, Leiden: 323-345.

DiXon, P. \& IRVINE, L. 1977. Seaweeds of the British Isles, vol 1 Rhodophyta. London: Natural History Museum.

DIXON, P.S. 1967. The typification of Fucus cartilagineus L. and F. corneus Huds. Blumea-Biodiversity, Evolution and Biogeography of Plants 15: 55-62.

EZARD, T., FuJISAWA, T. \& BARRAClOUGH, T. 2009. SPLITS: species' limits by threshold statistics. $R$ package version 1.

FISHER, R.A. 1935. The logic of inductive inference. Journal of the royal statistical society 98 : $39-82$.

Francavilla, M., Manara, P., Kamaterou, P., Monteleone, M. \& Zabaniotou, A. 2015. Cascade approach of red macroalgae Gracilaria gracilis sustainable valorization by extraction of phycobiliproteins and pyrolysis of residue. Bioresource technology 184: 305-313.

Fraser, C.I., HAy, C.H., SPENCER, H.G. \& WATERS, J.M. 2009. Genetic and morphological analyses of the southern bull kelp Durvillaea antarctica (Phaeophyceae: Durbillaeales) in New Zealand reveal cryptic species. Journal of Phycology 45: 436-443.

FrederiCQ, S., HoMmersand, M.H. \& FreshWATER, D.W. 1996. The molecular systematics of some agar-and carrageenan-containing marine red algae based on rbcL sequence analysis. Hydrobiologia 326: 125-135.

FRESHWATER, D.W. \& RUENESS, J. 1994. Phylogenetic relationships of some European Gelidium (Gelidiales, Rhodophyta) species, based on rbcL nucleotide sequence analysis. Phycologia 33: 187-194.

Freshwater, D.W., FredericQ, S., Butler, B.S., Hommersand, M.H. \& CHASE, M.W. 1994. A gene phylogeny of the red algae (Rhodophyta) based on plastid rbcL. Proceedings of the National Academy of Sciences 91: 7281-7285.

GABRIELSON, P.W., GARBARY, D.J. \& SCAGEL, R.F. 1985. The nature of the ancestral red alga: inferences from a cladistic analysis. BioSystems 18: 335-346.

GAMFEldT, L., LEFCHECK, J.S., BYRneS, J.E.K., CARDinale, B.J., DufFY, J.E. \& GRIFFIN, J.N. 2015. Marine biodiversity and ecosystem functioning: what's known and what's next? Oikos 124: 252-265.

GLEDITSCH, J.G. 1764. Systema plantarum a staminum situ.

Goff, L.J., Moon, D.A., Nyvall, P., Stache, B., Mangin, K. \& Zuccarello, G. 1996. The evolution of parasitism in the red algae: Molecular comparisons of adelphoparasites and their hosts. Journal of Phycology 32: 297-312. 
Gordon, D.P., Beaumont, J., MacDiarmid, A., Robertson, D.A. \& Ahyong, S.T. 2010. Marine biodiversity of Aotearoa New Zealand. PLoS One 5: e10905.

Guillemin, M.-L., VAlero, M., FAugeron, S., Nelson, W. \& Destombe, C. 2014. Tracing the trans-Pacific evolutionary history of a domesticated seaweed (Gracilaria chilensis) with archaeological and genetic data. PloS one 9: e114039.

GUIRY, M.D. \& GUIRY, G.M. 2016. Algaebase. In World-wide elctronic Publication. National University of Ireland, Galway.

GuRgel, C.F.D. \& LOPEZ - BAuTiSTA, J. 2007. Red algae. eLS.

HARPER, J.T. \& SAUNDERS, G.W. 2001. Molecular systematics of the Florideophyceae (Rhodophyta) using nuclear large and small subunit rDNA sequence data. Journal of phycology 37: 1073-1082.

HARVEY, W., MACKAY, J. \& MACKAY, J. 1836. Flora Hibernica, part third, algae. MACKAY, J. T., Flora hibernica comprising the flowering plants ferns characeae musci hepaticae lichenes and algae of Ireland arranged according to the natural system with a synopsis of the genera according to the Linnaean system 2: 279.

HeBert, P.D.N., CywinsKa, A. \& BALl, S.L. 2003. Biological identifications through DNA barcodes. Proceedings of the Royal Society of London B: Biological Sciences 270: 313-321.

Hewitt, C.L., Willing, J., Bauckham, A., Cassidy, A.M., Cox, C.M.S., Jones, L. \& WotTon, D.M. 2004. New Zealand marine biosecurity: delivering outcomes in a fluid environment. New Zealand Journal of Marine and Freshwater Research 38: 429-438.

Hillis, D.M., Moritz, C., Mable, B.K. \& Olmstead, R.G. 1996. Molecular systematics. Sinauer Associates Sunderland, MA.

Hind, K.R., GABrielson, P.W., Lindstrom, S.C. \& MARTone, P.T. 2014. Misleading morphologies and the importance of sequencing type specimens for resolving coralline taxonomy (Corallinales, Rhodophyta): Pachyarthron cretaceum is Corallina officinalis. Journal of Phycology 50: 760-764.

HOOKER, S.J.D. \& HARVEY, W.H. 1845. Algae Antarctica: being characters and descriptions of the hitherto unpublished species of Algae, discovered in Lord Auckland's Group, Campbell's Island, Kerguelen's Land, Falkland Islands, Cape Horn and other southern circumpolar regions, during the voyage of HM discovery-ships" Erebus" and" Terror".

Hotelling, H. 1933. Analysis of a complex of statistical variables into principal components. Journal of educational psychology 24: 417.

HuBERT, N. \& HANNER, R. 2015. DNA Barcoding, species delineation and taxonomy: a historical perspective. DNA Barcodes 3: 44-58.

Hughey, J.R., Silva, P.C. \& Hommersand, M.H. 2001. Solving taxonomic and nomenclatural problems in Pacific Gigartinaceae (Rhodophyta) using DNA from type material. Journal of phycology 37: 1091-1109.

HugheY, J.R. \& GABRIELSON, P.W. 2012. Comment on "Acquiring DNA sequence data from dried archival red algae (Florideophyceae) for the purpose of applying available names to contemporary genetic species: a critical assessment" 11 Appears in Botany 90 (3): 191-203. doi: 10.1139/b11-079. Botany 90: 1191-1194.

IRYU, Y., BASSI, D. \& WOELKERLING, W.J. 2009. Re-assessment of the type collections of fourteen Corallinalean species (Corralinalses, Rhodophyta) described by W. Ishjima (1942-1960). Palaeontology 52: 401-427. 
KATOH, K., Misawa, K., Kuma, K.I. \& MiYata, T. 2002. MAFFT: a novel method for rapid multiple sequence alignment based on fast Fourier transform. Nucleic acids research 30: 3059-3066.

KIMURA, M. 1968. Evolutionary rate at the molecular level. Nature 217: 624-626.

KLADI, M., VAGIAS, C. \& Roussis, V. 2004. Volatile halogenated metabolites from marine red algae. Phytochemistry Reviews 3: 337-366.

KÜTZING, F.T. 1843. Phycologia generalis: oder Anatomie, Physiologie und Systemkunde der Tange. Brockhaus.

KYLIN, H. 1928. Entwicklungsgeschichtliche Florideenstudien. na.

KYLIN, H. 1930. uber die Entwicklungsgeschichtliche Florideenstudien.

LAMOUROUX, J.V. 1813. Essai sur les genres de la famille des thalassiophytes non articulées. de l'imprimerie de A. Belin.

LEFCHECK, J.S., BYRNES, J.E.K., ISBELL, F., GAMFELDT, L., GRIFFIN, J.N., Eisenhauer, N., Hensel, M.J.S., Hector, A., CARdinale, B.J. \& DufFy, J.E. 2015. Biodiversity enhances ecosystem multifunctionality across trophic levels and habitats. Nature communications 6.

LEHMKUHL, K.V. 2003. Investigations Into the Diversity and Molecular Relatedness of the European Species of the Red Algal Genus Plocamium (Plocamiales, Florideophyceae): Recognizing Cryptic Species. University of New Brunswick (Canada).

Leliaert, F., Verbruggen, H., Vanormelingen, P., Steen, F., LóPez-Bautista, J.M., ZuCCARELlO, G.C. \& DE ClERCK, O. 2014. DNA-based species delimitation in algae. European Journal of Phycology 49: 179-196.

LinNAEUS, C.v. 1753. Species plantarum, 2 vols. Salvius, Stockholm.

LOPEZ-BAUTISTA, J.M. 2010. Red algal genomics: a synopsis. In Red Algae in the Genomic Age. pp. 227-240. Springer.

Loreau, M., Naeem, S., Inchausti, P., Bengtsson, J., Grime, J., Hector, A., HoOPER, D., Huston, M., RAFFAELli, D. \& SCHMID, B. 2001. Biodiversity and ecosystem functioning: current knowledge and future challenges. science 294: 804-808.

Machín - Sánchez, M., Rousseau, F., Le Gall, L., Cassano, V., Neto, A.I., SEntíEs, A., FujII, M.T. \& María CANDElaria, G.R. 2016. Species diversity of the genus Osmundea (Ceramiales, Rhodophyta) in the Macaronesian region. Journal of phycology.

Maggs, C.A., Verbruggen, H. \& De Clerck, O. 2007. Molecular systematics of red algae: building future structures on firm foundations. Systematics association special volume 75: 103.

MankTElow, M. 2010. History of taxonomy. Lecture from Dept. of Systematic Biology, Uppsala University. DOI= http://atbi. eu/summerschool/files/summerschool/Manktelow_Syllabus. pdf.

MANNHEIMER, C.A. 1999. An Overview Of Chemotaxonomy And Its Role In Creating A Phylogenetic Classification System.

MARsh, J.A. 1970. Primary Productivity of Reef - Building Calcareous Red Algae. Ecology 51: 255-263.

MASCHEK, J.A. \& BAKER, B.J. 2008. The chemistry of algal secondary metabolism. In Algal chemical ecology. pp. 1-24. Springer.

MCKelveY, B. 1982. Organizational systematics--taxonomy, evolution, classification. Univ of California Press. 
McNeill, J., Barrie, F., Burdet, H., Demoulin, V., Hawksworth, D., Marhold, K., Nicolson, D., Prado, J., Silva, P. \& Skog, J. 2006. International Code of Botanical Nomenclature (Vienna Code) Journal or equivalent: Book. Book Chapter.

MOESTRUP, Ø. 2001. Algal taxonomy: historical overview. eLS.

Moritz, C., HiLlis, D.M. \& MABLE, B.K. 1990. Molecular systematics. Sinauer Associates Sunderland, MA.

Muangmai, N., WeSt, J.A. \& ZuCCARELlo, G.C. 2014. Evolution of four Southern Hemisphere Bostrychia (Rhodomelaceae, Rhodophyta) species: phylogeny, species delimitation and divergence times. Phycologia 53: 593-601.

MuANGMAI, N. 2015. Unraveling the secret life of cryptic algal species: evolution, phylogeography and eco-physiology of the red alga, Bostrychia intricata.

NARASIMHARAO, B.P., ANAND, N., VIDYASHANKAR, S. \& SARADA, R. 2012. Algal Technologies and Challenges to Universities: New Approaches to Reach Out to Society. Asian Biotechnology \& Development Review 14.

NAYLOR, S., HANKE, F.J., MANES, L.V. \& CREWS, P. 1983. Chemical and biological aspects of marine monoterpenes. In Fortschritte der Chemie organischer Naturstoffe/Progress in the Chemistry of Organic Natural Products. pp. 189241. Springer.

NeIGE, P. 2006. Morphometrics of hard structures in cuttlefish. Vie et Milieu 56: 121128.

NELSON, W.A., DALEN, J. \& NEILL, K.F. 2013. Insights from natural history collections: analysing the New Zealand macroalgal flora using herbarium data. PhytoKeys: 1 .

Nelson, W.A. 2013. New Zealand seaweeds: an illustrated guide. Te Papa Press.

Nelson, W.A., Sutherland, J.E., FArR, T.J., Hart, D.R., Neill, K.F., Kim, H.J. \& YoON, H.S. 2015. Multi - gene phylogenetic analyses of New Zealand coralline algae: Corallinapetra Novaezelandiae gen. et sp. nov. and recognition of the Hapalidiales ord. nov. Journal of Phycology.

Norton, T.A., Melkonian, M. \& Andersen, R.A. 1996. Algal biodiversity*. Phycologia 35: 308-326.

Oliveira, M.C. \& BhatTacharya, D. 2000. Phylogeny of the Bangiophycidae (Rhodophyta) and the secondary endosymbiotic origin of algal plastids. Journal of Phycology 36: 52-52.

Padial, J.M., Miralles, A., De la Riva, I. \& Vences, M. 2010. The integrative future of taxonomy. Frontiers in zoology 7: 1.

Paradas, W.C., Crespo, T.M., Salgado, L.T., Andrade, L.R., SoAres, A.R., Hellio, C., Paranhos, R.R., Hill, L.J., Souza, G.M. \& Kelecom, A.G.A.C. 2015. Mevalonosomes: specific vacuoles containing the mevalonate pathway in Plocamium brasiliense cortical cells (Rhodophyta). Journal of phycology 51: 225-235.

PARSONS, M.J. 1985. New Zealand seaweed flora and its relationships*. New Zealand Journal of Marine and Freshwater Research 19: 131-138.

Payo, D.A., Leliaert, F., Verbruggen, H., D'HOndt, S., Calumpong, H.P. \& De CLERCK, O. 2013. Extensive cryptic species diversity and fine-scale endemism in the marine red alga Portieria in the Philippines. In Proc. R. Soc. B. pp. 20122660. The Royal Society.

PEARSON, K. 1895. Note on regression and inheritance in the case of two parents. Proceedings of the Royal Society of London 58: 240-242. 
PEARSON, K. 1901. LIII. On lines and planes of closest fit to systems of points in space. The London, Edinburgh, and Dublin Philosophical Magazine and Journal of Science 2: 559-572.

Pedersen, S.F., MELAND, M. \& REBOURS, C. 2013. Macroalgae for an increasing organic market. Bioforsk Fokus 8: 337-338.

Pelletreau, K.N. \& TARGETT, N.M. 2008. New perspectives for addressing patterns of secondary metabolites in marine macroalgae. In Algal Chemical Ecology. pp. 121-146. Springer.

Perkins, D.M., Bailey, R.A., Dossena, M., Gamfeldt, L., Reiss, J., Trimmer, M. \& WOODWARD, G. 2015. Higher biodiversity is required to sustain multiple ecosystem processes across temperature regimes. Global change biology 21: 396-406.

PHILLIPS, J.A. 2001. Marine macroalgal biodiversity hotspots: why is there high species richness and endemism in southern Australian marine benthic flora? Biodiversity \& Conservation 10: 1555-1577.

Puillandre, N., Lambert, A., Brouillet, S. \& Achaz, G. 2012. ABGD, Automatic Barcode Gap Discovery for primary species delimitation. Molecular Ecology 21: 1864-1877.

Rambaut, A., Suchard, M., XIE, D. \& Drummond, A. 2014. Tracer v1. 6. RASBAND, W. 1997. ImageJ. US National Institutes of Health, Bethesda, MD.

Rawlence, N.J., Kennedy, M., Anderson, C.N.K., Prost, S., Till, C.E., Smith, I.W.G., SCOFIELD, R.P., TENNYSON, A.J.D., HAMEL, J. \& LALAS, C. 2015. Geographically contrasting biodiversity reductions in a widespread New Zealand seabird. Molecular ecology.

Robuchon, M., Valero, M., Gey, D. \& Le Gall, L. 2015. How does molecularassisted identification affect our estimation of $\alpha, \beta$ and $\gamma$ biodiversity? An example from understory red seaweeds (Rhodophyta) of Laminaria kelp forests in Brittany, France. Genetica 143: 207-223.

RonQuist, F. \& HUELSENBECK, J.P. 2003. MrBayes 3: Bayesian phylogenetic inference under mixed models. Bioinformatics 19: 1572-1574.

SAN-MARTín, A. \& RovirosA, J. 1986. Variations in the halogenated monoterpene metabolites of Plocamium cartilagineum of the Chilean coast. Biochemical systematics and ecology 14: 459-461.

SAUNDERS, G.W. \& KRAFT, G.T. 1994. Small-subunit rRNA gene sequences from representatives of selected families of the Gigartinales and Rhodymeniales (Rhodophyta). 1. Evidence for the Plocamiales ord. nov. Canadian Journal of Botany 72: 1250-1263.

SAUNDERS, G.W. \& HommerSAND, M.H. 2004. Assessing red algal supraordinal diversity and taxonomy in the context of contemporary systematic data. American Journal of Botany 91: 1494-1507.

SAUNDERS, G.W. \& LEHMKUHL, K.V. 2005. Molecular divergence and morphological diversity among four cryptic species of Plocamium (Plocamiales, Florideophyceae) in northern Europe. European Journal of Phycology 40: 293-312.

SAUNDERS, G.W. 2005. Applying DNA barcoding to red macroalgae: a preliminary appraisal holds promise for future applications. Philosophical transactions of the Royal Society B: Biological sciences 360: 1879-1888.

SAUNDERS, G.W. 2008. A DNA barcode examination of the red algal family Dumontiaceae in Canadian waters reveals substantial cryptic species diversity. 1. The foliose Dilsea-Neodilsea complex and Weeksia This paper is one of a 
selection of papers published in the Special Issue on Systematics Research. Botany 86: 773-789.

SCHIPPERS, P., HEMERIK, L., BAVECO, J.M. \& VERBOOM, J. 2015. Rapid Diversity Loss of Competing Animal Species in Well-Connected Landscapes. PloS one 10.

Schlick-Steiner, B.C., Steiner, F.M., Seifert, B., Stauffer, C., Christian, E. \& CROZIER, R.H. 2010. Integrative taxonomy: a multisource approach to exploring biodiversity. Annual review of entomology 55: 421-438.

SCHMITZ, F. 1883. Untersuchungen über die Befruchtung der Florideen. Reichsdruckerei.

SCHMITZ, F. 1892. [Klasse Rhodophyceae] 2. Unterklasse Floridae. In: Syllabus der vorlesungen über specielle und medicinisch-pharmaceutische Botanik. Grosse Ausgabe. Gebrüder Borntraeger, Berlin.

SEARLES, R.B. 1980. The strategy of the red algal life history. American Naturalist: 113-120.

SECKBACH, J. \& CHAPMAN, D.J. 2010. Red algae in the genomic age. Springer Science \& Business Media.

SimONS, R.H. 1964. Species of Plocamium on the South African coast. Bothalia 8: 183-193.

SJÖSTEDT, L.G. 1926. Floridean studies. CWK Gleerup.

SouTH, G.R. \& ADAMS, N.M. 1979. Revision of the genus Plocamium Lamouroux (Rhodophyta, Gigartinales) in New Zealand. Phycologia 18: 120-132.

STAMATAKIS, A. 2006. RAxML-VI-HPC: maximum likelihood-based phylogenetic analyses with thousands of taxa and mixed models. Bioinformatics 22: 26882690.

Tilman, D., May, R.M., Lehman, C.L. \& NowaK, M.A. 1994. Habitat destruction and the extinction debt.

TILmAn, D. 1996. Biodiversity: population versus ecosystem stability. Ecology 77: 350-363.

Tilman, D., Isbell, F. \& Cowles, J.M. 2014. Biodiversity and ecosystem functioning. Annual Review of Ecology, Evolution, and Systematics 45: 471.

TIMMERS, M.A., DiAs, D.A. \& URBAN, S. 2012. Application of HPLC-NMR in the Identification of Plocamenone and Isoplocamenone from the Marine Red Alga Plocamium angustum. Marine drugs 10: 2089-2102.

TURNER, D. 1807-1808. Fuci, sive, Plantarum Fucorum generi a botanicis ascriptarum icones descriptiones et historia. Typis J. M'Creery, Impensis J. et A. Arch in vico Cornhill dicto.

VAN DEN Hoek, C., MAnN, D. \& JAhns, H.M. 1996. Algae: an introduction to phycology. Cambridge university press.

Verbruggen, H., De Clerck, O., Kooistra, W.H. \& CopPejans, E. 2005. Molecular and morphometric data pinpoint species boundaries in Halimeda section Rhipsalis (Bryopsidales, Chlorophyta). Journal of Phycology 41: 606-621.

WHITTAKER, R.J., WILLIS, K.J. \& FIELD, R. 2001. Scale and species richness: towards a general, hierarchical theory of species diversity. Journal of Biogeography 28: 453-470.

WILEY, E.O. \& LIEBERMAN, B.S. 2011. Phylogenetics: theory and practice of phylogenetic systematics. John Wiley \& Sons.

WiLl, K.W., MishleR, B.D. \& WheElER, Q.D. 2005. The Perils of DNA Barcoding and the Need for Integrative Taxonomy. Systematic Biology 54: 844-851. 
Womersley, H. 1971. The genus Plocamium (Rhodophyta) in southern Australia. Trans. R. Soc. S. Aust 95: 9-27.

Worm, B., Barbier, E.B., Beaumont, N., Duffy, J.E., Folke, C., HalPern, B.S., JACKSON, J.B.C., LOTZE, H.K., Micheli, F. \& PALUMBI, S.R. 2006. Impacts of biodiversity loss on ocean ecosystem services. science 314: 787-790.

Wright, J., DE NYS, R. \& STEINBERG, P. 2000. Geographic variation in halogenated furanones from the red alga Delisea pulchra and associated herbivores and epiphytes. Marine Ecology Progress Series 207: 227-241.

Wright, J., De Nys, R., Poore, A. \& Steinberg, P. 2004. Chemical defense in a marine alga: heritability and the potential for selection by herbivores. Ecology 85: 2946-2959.

WynNE, M.J. 2002a. Plocamium cirrhosum comb. nov.(Plocamiales, Rhodophyta) to replace P. costatum. New Zealand Journal of Botany 40: 137-142.

WYNNE, M.J. 2002b. A description of Plocamium fimbriatum sp. nov.(Plocamiales, Rhodophyta) from the Sultanate of Oman, with a census of currently recognized species in the genus. Nova Hedwigia 75: 333-356.

YANO, T., KAMIYA, M., ARAI, S. \& KAWAI, H. 2004. Morphological homoplasy in Japanese Plocamium species (Plocamiales, Rhodophyta) inferred from the Rubisco spacer sequence and intracellular acidity. Phycologia 43: 383-393.

Yeates, D.K., Seago, A., Nelson, L., Cameron, S.L., Joseph, L. \& Trueman, J.W. 2011. Integrative taxonomy, or iterative taxonomy? Systematic Entomology 36: 209-217.

Yoon, H.S., Hackett, J.D., Pinto, G. \& Bhattacharya, D. 2002. The single, ancient origin of chromist plastids. Journal of Phycology 38: 40-40.

YoOn, H.S., MÜLLER, K.M., SHEATH, R.G., OtT, F.D. \& BHATTACHARYA, D. 2006. Defining the major lineages of red algae (Rhodophyta) 1. Journal of Phycology 42: 482-492.

Yoon, H.S., ZucCAREllo, G.C. \& BhatTACHARYA, D. 2010. Evolutionary history and taxonomy of red algae. In Red algae in the genomic age. pp. 25-42. Springer.

Young, R.M., Von SAlm, J.L., Amsler, M.O., LoPeZ-BAutista, J., AmSler, C.D., MCCLINTOCK, J.B. \& BAKER, B.J. 2013. Site-specific variability in the chemical diversity of the Antarctic red alga Plocamium cartilagineum. Marine drugs 11: 2126-2139.

Zhang, J., Kapli, P., PAVlidis, P. \& Stamatakis, A. 2013. A general species delimitation method with applications to phylogenetic placements. Bioinformatics 29: 2869-2876.

Zinetti, F., Dapporto, L., VAnni, S., Magrini, P., Bartolozzi, L., Chelazzi, G. \& CiOFI, C. 2013. Application of molecular genetics and geometric morphometrics to taxonomy and conservation of cave beetles in central Italy. Journal of insect conservation 17: 921-932.

ZuCCARELLO, G.C. \& WeST, J.A. 2003. Multiple cryptic species: molecular diversity and reproductive isolation in the Bostrychia radicans/B. moritziana complex (Rhodomelaceae, Rhodophyta) with focus on North American isolates. Journal of Phycology 39: 948-959.

ZUCCARELLO, G.C. \& LOKHORST, G.M. 2005. Molecular phylogeny of the genus Tribonema (Xanthophyceae) using rbc L gene sequence data: monophyly of morphologically simple algal species. Phycologia 44: 384-392.

ZuCCARELlO, J. 2014. New Zealand seaweeds: an illustrated guide. Phycologia 53: 203-204. 


\section{Supplementary Information}

\section{Appendix A}

Table A.1. Downloaded COI sequences from Genbank used in phylogenetic analyses inclusive of species name and Genbank Accession Number.

\begin{tabular}{|c|c|c|}
\hline Species & Genbank Accession No. & Country of Origin \\
\hline Plocamium cf. angustum 1 & JF271616 & AUS \\
\hline Plocamium cf. angustum 3 & JF271655 & AUS \\
\hline Plocamium cf. angustum NZ2 & JF271634 & NZL \\
\hline Plocamium cartilagineum & JF271582 & ESP \\
\hline Plocamium cirrhosum 1 & $\mathrm{JF} 271625$ & AUS \\
\hline Plocamium cirrhosum 2 & JF271646 & AUS \\
\hline Plocamium dilatatum & JF271585 & AUS \\
\hline Plocamium fimbriatum & JF271587 & OMN \\
\hline Plocamium haratum & JF271589 & AUS \\
\hline Plocamium leptophyllum 1 & JF271626 & AUS \\
\hline Plocamium leptophyllum 2 & JF271649 & AUS \\
\hline Plocamium lyngbyanum & JF271601 & ESP \\
\hline Plocamium maggsiae & JF271602 & IRE \\
\hline Plocamium mertensii & HQ919529 & AUS \\
\hline Plocamium microcladioides & JF271603 & ZAF \\
\hline Plocamium nanum & JF271606 & FRA \\
\hline Plocamium oregonum & JF271608 & USA \\
\hline Plocamium patagiatum & JF271611 & AUS \\
\hline Plocamium pacificum & KM254709 & USA \\
\hline Plocamium cf. pacificum & JF271628 & CAN \\
\hline Plocamium preissianum & JF271613 & AUS \\
\hline Plocamium raphelisianum & JF271615 & ESP \\
\hline Plocamium sandvicense & HQ422902 & USA \\
\hline Plocamium suhrii & JF271667 & ZAF \\
\hline Plocamium telefairiae & KC782865 & CHN \\
\hline Plocamium cf. telefairiae & JF271632 & ZAF \\
\hline Plocamium violaceum & JF271670 & CAN \\
\hline Sarcodia ciliata* & FJ499662 & AUS \\
\hline
\end{tabular}


Table A.2. List of redundant sequences identified by McClade, recorded as Specimen Number (No.) paired with respective identical specimen numbers.

\begin{tabular}{ll} 
Specimen No. & Identical Specimen No. \\
\hline A50 & A47, A48, A51, R9, R19 \\
A31 & A5, A18, A23, A24, A46, R20, R23 \\
A30 & A40 \\
A90 & A89 \\
R24 & A3, A11, A54, A66 \\
A15 & A16 \\
A1 & A2, A72, R18
\end{tabular}


Table A.3.1. List of specimen used for $r b c \mathrm{~L}$ phylogenetic analyses.

Specimen No.

\begin{tabular}{cc}
\hline A1 & A62 \\
A6 & A72 \\
A10 & A74 \\
A15 & A77 \\
A30 & A83 \\
A40 & A84 \\
A41 & A90 \\
A50 & A80 \\
A59 & B4 \\
B10 &
\end{tabular}

Table A.3.2. Downloaded $r b c \mathrm{~L}$ sequences from Genbank used in phylogenetic analyses inclusive of species name and Genbank Accession Number.

\begin{tabular}{lll} 
Species & Genbank Accession No. & Country of Origin \\
\hline Plocamium angustum & U261703 & NZL \\
Plocamium brasiliense & KM974718 & BRA \\
Plocamium brasiliense & KM974717 & BRA \\
Plocamium cartilagineum & HQ224543 & NZL \\
Plocamium cartilagineum & U26817 & CHL \\
Plocamium cartilagineum & U26818 & ATA \\
Plocamium cartilagineum & KF158993 & ATA \\
Plocamium cartilagineum & KF158992 & ATA \\
Plocamium cartilagineum & U21701 & IRE \\
Plocamium cartilagineum & KF469218 & KOR \\
Plocamium cartilagineum & U04211 & USA \\
Plocamium cirrhosum & KC174809 & NZL \\
Plocamium coleorhiza & U21700 & ZAF \\
Plocamium cornutum & U21704 & ZAF \\
Plocamium maggsiae & JX969788 & IRE \\
Plocamium serrulatum & KC174810 & TWN \\
Plocamium sp. & U26821 & NZL \\
Plocamium telfairiae & U21702 & JPN \\
Plocamium telfairiae & KF69219 & KOR \\
Sarcodia ciliata* & JX969793 & AUS \\
Sarcodia marginata* & AF212193 & AUS \\
$*$ Outgroup & & \\
& &
\end{tabular}


Table A.4.1. List of specimen used for LSU phylogenetic analyses.

\section{Specimen No.}

\begin{tabular}{cc}
\hline A1 & A62 \\
A6 & A72 \\
A10 & A74 \\
A15 & A77 \\
A30 & A80 \\
A40 & A84 \\
A41 & A90 \\
A50 & A98 \\
A59 & B4 \\
B10 & B7
\end{tabular}

Table A.4.2. Downloaded LSU sequences from Genbank used in phylogenetic analyses inclusive of species name and Genbank Accession Number.

\section{Species}

Plocamium angustum

Plocamium cartilagineum

Plocamium cirrhosum

Plocamium hamatum

Plocamium leptophyllum

Plocamium maggsiae

Plocamium mertensii

Plocamium nanum

Plocamium oregonum

Plocamium pacificum

Plocamium patagiatum

Plocamium preissianum

Plocamium pulvinata

Plocamium sp.

Plocamium sp.

Plocamium sp.

Plocamium subtile

Plocamium telfairiae

Plocamium telefairiae

Plocamium violaceum

Sarcodia ciliata*

Sarcodia marginata*
Genbank Accession No. Country of Origin

AY881711 AUS

AY881708 FRA

AY881714 AUS

AY881715 AUS

AY881716 AUS

AF419141 IRE

AY881717 AUS

AY881710 FRA

AY881724 USA

AY881722 CAN

AY881718 AUS

AY881719 AUS

AY881721 CAN

AY881712 AUS

AY881713 AUS

AY881720 AUS

AY881709 FRA

AY881725 KOR

AY881726 KOR

AY881723 CAN

DQ343708 AUS

DQ373709 AUS 
Table A.5. List of specimens used for combined LSU/COI phylogenetic analyses.

Specimen No.

\begin{tabular}{cc}
\multicolumn{2}{c}{ Specimen No. } \\
\hline A1 & A62 \\
A6 & A72 \\
A10 & A74 \\
A15 & A77 \\
A30 & A80 \\
A40 & A84 \\
A41 & A90 \\
A50 & A98 \\
A59 & B4 \\
B10 & B7
\end{tabular}

Table A.6. List of specimens used for morphometric analyses.

Specimen No.

\begin{tabular}{cc}
\multicolumn{2}{c}{ Specimen No. } \\
\hline A10 & A1 \\
A85 & A2 \\
A80 & A72 \\
A12 & A87 \\
A90 & A98 \\
A89 & A83 \\
B4 & A70 \\
A3 & A82 \\
A4 & A59 \\
A11 & A74 \\
A66 & A84 \\
A94 & A6 \\
A95 & B7 \\
A100 & A77 \\
R20 & A73 \\
A96 & B5
\end{tabular}




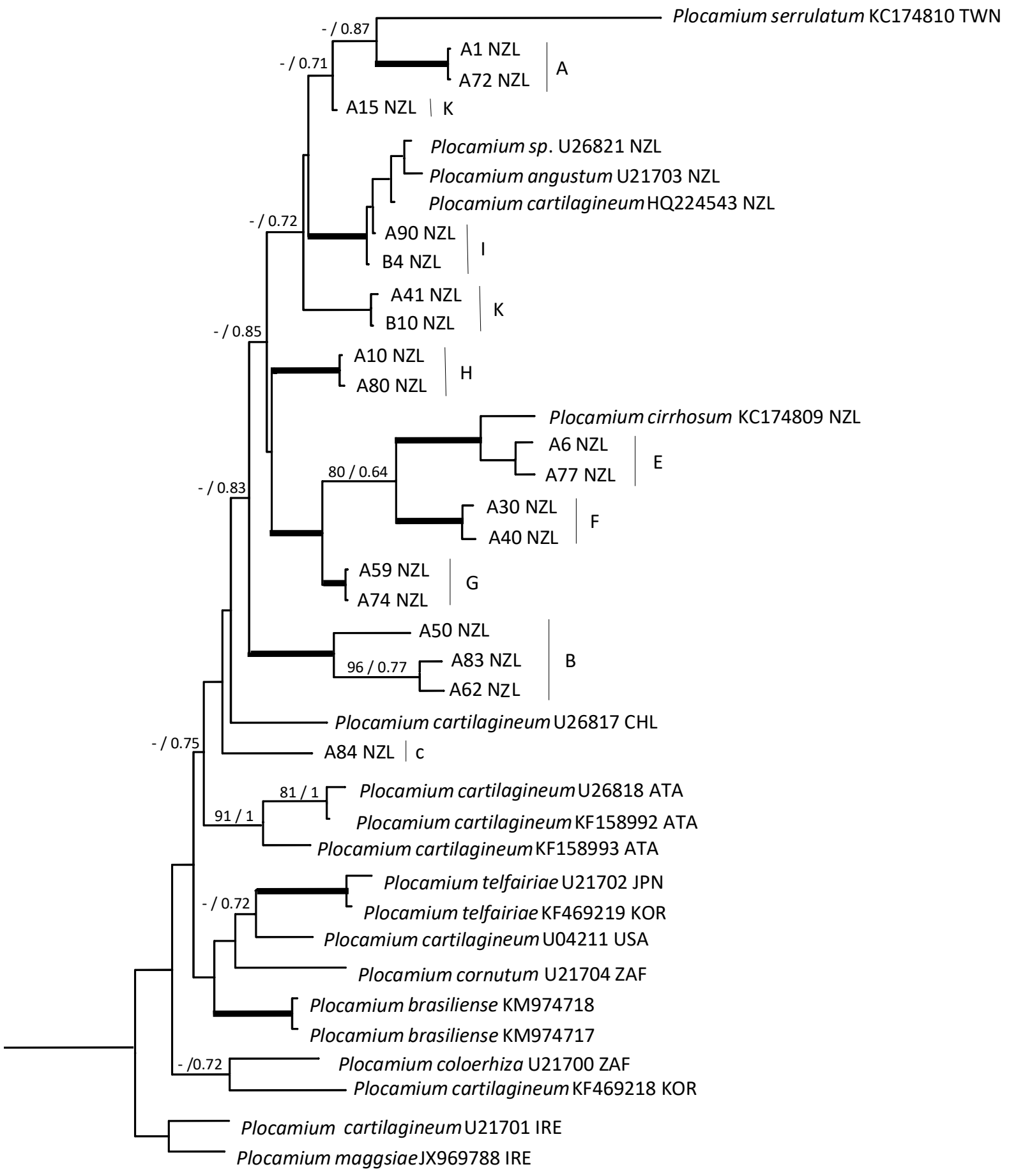

Fig. A.1. Phylogenetic tree generated using Bayesian Inference inferred from partial $r b c \mathrm{~L}$ sequences (with BI > 0.70 and ML bootstrap values $>75 \%$ ). Bold branches indicate strongly supported branches (BI $>0.98$ and $\mathrm{ML}$ bootstraps $>95 \%$ ), as well as labels (A to K) for candidate species groups. 


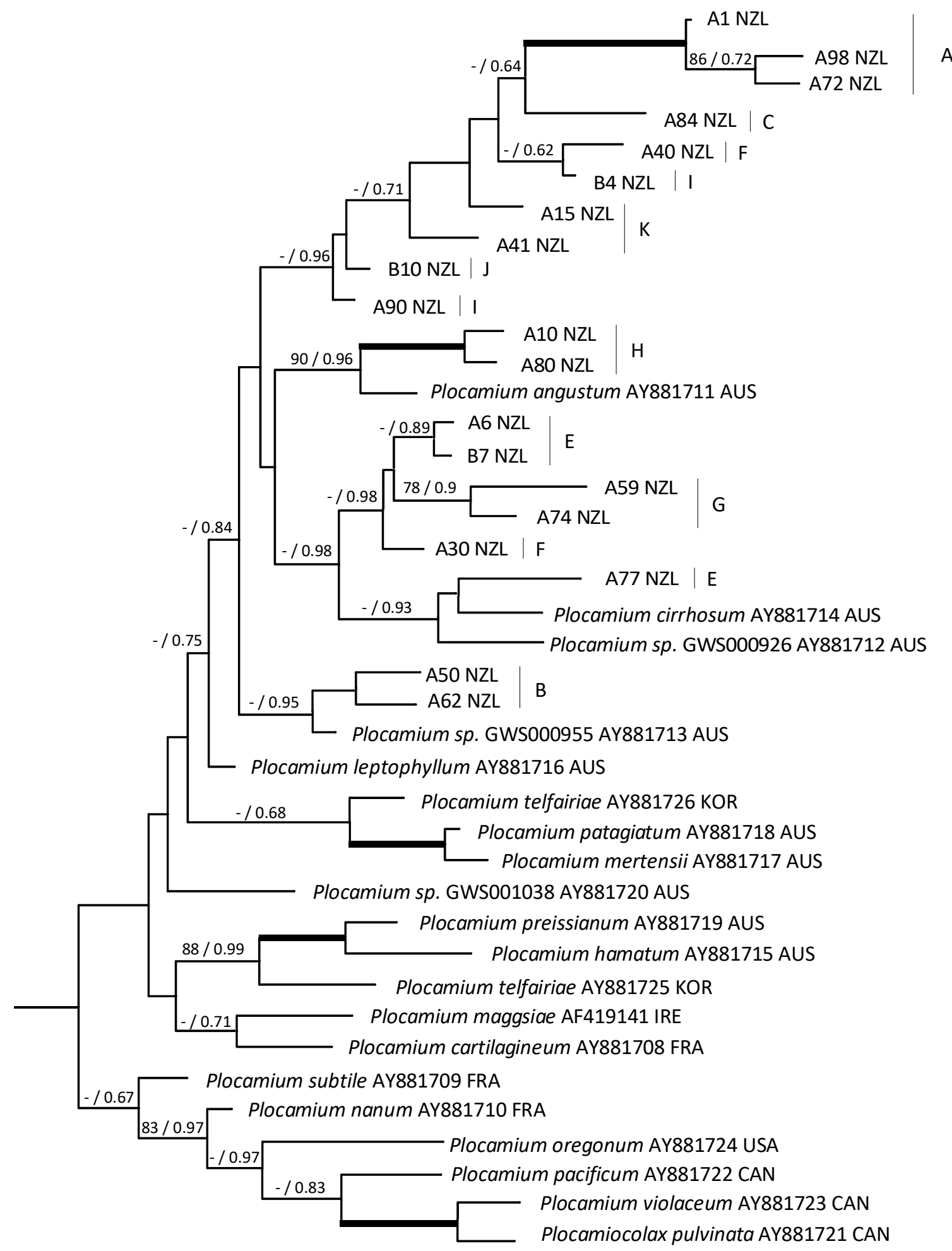

Fig. A.2. Phylogenetic tree generated using Bayesian Inference inferred from partial LSU sequences (with BI > 0.70 and ML bootstrap values $>75 \%$ ). Bold branches indicate strongly supported branches (BI $>0.98$ and $\mathrm{ML}$ bootstraps $>95 \%$ ), as well as labels (A to K) for candidate species groups. 
Table A.7. Correlations between the original variables and the first two principal components in the PCA for the 9 candidate species of the Plocamium species tested in the analysis. See Materials and Methods for an expansion of the variables abbreviated here.

\begin{tabular}{l|c|c}
\hline Variable & Principal Component 1 & Principal Component 2 \\
\hline WMA & 0.450 & -0.188 \\
WLBR & 0.466 & -0.238 \\
LLBR & 0.444 & 0.289 \\
NASR & -0.412 & -0.247 \\
ANRAS & -0.013 & 0.680 \\
CBR & -0.166 & -0.489 \\
SERBR & 0.431 & -0.247 \\
\hline
\end{tabular}

Table A.8. Predicted results of the Discriminant Analysis. The table indicates $97.14 \%$ of the time (misclassified I as K one time), considering the chosen diagnostic characters conjointly, the analysis is able to correctly identify morphology reflective of genetic species delimitation.

\begin{tabular}{l|ccccccccccc} 
Candidate species & A & $\mathbf{B}$ & $\mathbf{C}$ & $\mathbf{E}$ & $\mathbf{G}$ & $\mathbf{H}$ & $\mathbf{I}$ & $\mathbf{J}$ & $\mathbf{K}$ & $\boldsymbol{P}$. cirrhosum & $\boldsymbol{P}$. microcladioides \\
\hline $\mathbf{A}$ & 6 & 0 & 0 & 0 & 0 & 0 & 0 & 0 & 0 & 0 & 0 \\
$\mathbf{B}$ & 0 & 3 & 0 & 0 & 0 & 0 & 0 & 0 & 0 & 0 & 0 \\
$\mathbf{C}$ & 0 & 0 & 1 & 0 & 0 & 0 & 0 & 0 & 0 & 0 & 0 \\
$\mathbf{E}$ & 0 & 0 & 0 & 6 & 0 & 0 & 0 & 0 & 0 & 0 & 0 \\
$\mathbf{G}$ & 0 & 0 & 0 & 0 & 2 & 0 & 0 & 0 & 0 & 0 & 0 \\
$\mathbf{H}$ & 0 & 0 & 0 & 0 & 0 & 4 & 0 & 0 & 0 & 0 & 0 \\
$\mathbf{I}$ & 0 & 0 & 0 & 0 & 0 & 0 & 2 & 0 & 0 & 0 & 0 \\
J & 0 & 0 & 0 & 0 & 0 & 0 & 0 & 1 & 0 & 0 & 0 \\
K & 0 & 0 & 0 & 0 & 0 & 0 & 1 & 0 & 6 & 0 & 1 \\
$P$. cirrhosum & 0 & 0 & 0 & 0 & 0 & 0 & 0 & 0 & 0 & 1 & 0 \\
$\boldsymbol{P . ~ m i c r o c l a d i o i d e s}$ & 0 & 0 & 0 & 0 & 0 & 0 & 0 & 0 & 0 & 0 &
\end{tabular}

Table A.9. MANOVA test criteria and F approximation for the hypothesis of no overall group effect indicating significant mean differences between "candidate species"

\begin{tabular}{|c|c|c|c|c|c|}
\hline Statistic & Value & F Value & $\begin{array}{c}\text { Num } \\
\text { DF }\end{array}$ & Den DF & $\operatorname{Pr}>\mathbf{F}$ \\
\hline Wilks' Lamba & $<0.001$ & 5.103 & 70 & 105.94 & $<0.0001$ \\
\hline Pillai's Trace & 3.900 & 2.895 & 70 & 161 & $<0.0001$ \\
\hline Hotelling-Lawley Trace & 39.097 & 8.5375 & 70 & 107 & $<0.0001$ \\
\hline Roy's Greatest Root & 26.542 & 61.407 & 10 & 23 & $<0.0001$ \\
\hline
\end{tabular}

Table A.10. One-Way ANOVA test criteria and F approximation for the individual characters analyzed. The results of each ANOVA indicate significant differences between at least two of the candidate species across all characters (WMA=Width of Main Axes, WLBR=Width of Lowest Basal Ramuli, Length of Lowest Basal Ramuli, Number of Alternating Series of Ramuli, Average number of Ramuli per Alternating Series, Curvature of the basal Ramuli, and Serration of Basal Ramuli).

\begin{tabular}{l|rrrr}
\multicolumn{1}{c}{ Character } & F Value & Num DF & Den DF & \multicolumn{1}{c}{ Pr $>$ F } \\
\hline WMA & 12.062 & 10 & 23 & $<0.0001$ \\
WLBR & 4.52 & 10 & 23 & 0.0013 \\
LLBR & 4.149 & 10 & 23 & 0.0023 \\
NASR & 8.052 & 10 & 23 & $<0.0001$ \\
ANRAS & 3.996 & 10 & 23 & 0.0029 \\
CBR & 2.859 & 10 & 23 & 0.018 \\
SERBR & 15.96 & 10 & 23 & $<0.0001$
\end{tabular}


Table A.11. Results of the Tukey Tests multiple comparison of means 95\% family-wise confidence level for WMA.

\begin{tabular}{|c|c|c|c|}
\hline Species & p-value & Species & p-value \\
\hline P. cirrhosum- & 0.006 & G-E & 1 \\
\hline P. microcladioides & & & \\
\hline B-A & 0.636 & $\mathrm{H}-\mathrm{E}$ & 0.001 \\
\hline C-A & 0.112 & $\mathrm{I}-\mathrm{E}$ & $<0.001$ \\
\hline E-A & 0.170 & $\mathrm{~J}-\mathrm{E}$ & 1 \\
\hline G-A & 0.834 & $\mathrm{~K}-\mathrm{E}$ & $<0.001$ \\
\hline $\mathrm{H}-\mathrm{A}$ & 0.191 & P. cirrhosum-E & 1 \\
\hline $\mathrm{I}-\mathrm{A}$ & 0.029 & P. microcladioides-E & $<0.001$ \\
\hline $\mathrm{J}-\mathrm{A}$ & 0.993 & $\mathrm{H}-\mathrm{G}$ & 0.035 \\
\hline $\mathrm{K}-\mathrm{A}$ & 0.004 & $\mathrm{I}-\mathrm{G}$ & 0.007 \\
\hline P. cirrhosum-A & 0.682 & $\mathrm{~J}-\mathrm{G}$ & 1 \\
\hline P. microcladioides-A & 0.019 & $\mathrm{~K}-\mathrm{G}$ & 0.002 \\
\hline C-B & 0.812 & P. cirrhosum-G & 1 \\
\hline E-B & 0.007 & P. microcladioides $-\mathrm{G}$ & 0.004 \\
\hline G-B & 0.136 & $\mathrm{I}-\mathrm{H}$ & 0.987 \\
\hline $\mathrm{H}-\mathrm{B}$ & 1 & $\mathrm{~J}-\mathrm{H}$ & 0.284 \\
\hline $\mathrm{I}-\mathrm{B}$ & 0.887 & $\mathrm{~K}-\mathrm{H}$ & 0.949 \\
\hline $\mathrm{J}-\mathrm{B}$ & 0.533 & P. cirrhosum-H & 0.051 \\
\hline K-B & 0.748 & P. microcladioides $-\mathrm{H}$ & 0.531 \\
\hline P. cirrhosum-B & 0.136 & $\mathrm{~J}-\mathrm{I}$ & 0.088 \\
\hline P. microcladioides-B & 0.357 & K-I & 1 \\
\hline E-C & 0.003 & P. cirrhosum-I & 0.013 \\
\hline $\mathrm{G}-\mathrm{C}$ & 0.024 & P. microcladioides-I & 0.937 \\
\hline $\mathrm{H}-\mathrm{C}$ & 0.938 & K-J & 0.052 \\
\hline $\mathrm{I}-\mathrm{C}$ & 1 & P. cirrhosum-J & 1 \\
\hline $\mathrm{J}-\mathrm{C}$ & 0.106 & P. microcladioides- $\mathrm{J}$ & 0.028 \\
\hline $\mathrm{K}-\mathrm{C}$ & 1 & P. cirrhosum-K & 0.006 \\
\hline P. cirrhosum-C & 0.024 & P. microcladioides-K & 0.918 \\
\hline P. microcladioides $-\mathrm{C}$ & 1 & & \\
\hline
\end{tabular}


Table A.12. Results of the Tukey Tests multiple comparison of means $95 \%$ family-wise confidence level for WLBR.

\begin{tabular}{|c|c|c|c|}
\hline Species & p-value & Species & p-value \\
\hline $\begin{array}{l}\text { P. cirrhosum- } \\
\text { P. microcladioides }\end{array}$ & 0.151 & G-E & 0.862 \\
\hline B-A & 0.804 & H-E & 0.050 \\
\hline C-A & 0.922 & I-E & 0.037 \\
\hline E-A & 0.560 & $J-E$ & 0.981 \\
\hline G-A & 1 & K-E & 0.001 \\
\hline $\mathrm{H}-\mathrm{A}$ & 0.850 & P. cirrhosum-E & 1 \\
\hline I-A & 0.684 & P. microcladioides $-\mathrm{E}$ & 0.061 \\
\hline $\mathrm{J}-\mathrm{A}$ & 1 & $\mathrm{H}-\mathrm{G}$ & 0.984 \\
\hline K-A & 0.136 & $\mathrm{I}-\mathrm{G}$ & 0.929 \\
\hline P. cirrhosum-A & 0.857 & $\mathrm{~J}-\mathrm{G}$ & 1 \\
\hline P. microcladioides-A & 0.456 & $\mathrm{~K}-\mathrm{G}$ & 0.606 \\
\hline C-B & 1 & P. cirrhosum-G & 0.908 \\
\hline E-B & 0.058 & P. microcladioides $-\mathrm{G}$ & 0.663 \\
\hline G-B & 0.967 & $\mathrm{I}-\mathrm{H}$ & 1 \\
\hline H-B & 1 & $\mathrm{~J}-\mathrm{H}$ & 0.996 \\
\hline I-B & 1 & $\mathrm{~K}-\mathrm{H}$ & 0.987 \\
\hline $\mathrm{J}-\mathrm{B}$ & 0.991 & P. cirrhosum-H & 0.347 \\
\hline K-B & 0.999 & P. microcladioides $-\mathrm{H}$ & 0.961 \\
\hline P. cirrhosum-B & 0.313 & J-I & 0.979 \\
\hline P. microcladioides $-\mathrm{B}$ & 0.987 & K-I & 1 \\
\hline E-C & 0.305 & P. cirrhosum-I & 0.255 \\
\hline G-C & 0.974 & P. microcladioides-I & 0.995 \\
\hline $\mathrm{H}-\mathrm{C}$ & 1 & K-J & 0.858 \\
\hline $\mathrm{I}-\mathrm{C}$ & 1 & P. cirrhosum-J & 0.968 \\
\hline $\mathrm{J}-\mathrm{C}$ & 0.988 & P. microcladioides-J & 0.793 \\
\hline $\mathrm{K}-\mathrm{C}$ & 1 & P. cirrhosum-K & 0.093 \\
\hline P. cirrhosum-C & 0.439 & P. microcladioides $-\mathrm{K}$ & 1 \\
\hline P. microcladioides-C & 1 & & \\
\hline
\end{tabular}


Table A.13. Results of the Tukey Tests multiple comparison of means $95 \%$ family-wise confidence level for LLBR.

\begin{tabular}{l|c|l|c} 
Species & p-value & Species & \multicolumn{1}{l}{ p-value } \\
\hline P. cirrhosum- & 0.055 & G-E & 1 \\
P. microcladioides & & & \\
B-A & 0.997 & H-E & 0.008 \\
C-A & 0.983 & I-E & 0.992 \\
E-A & 0.376 & J-E & 1 \\
G-A & 0.823 & K-E & 0.690 \\
H-A & 0.553 & P. cirrhosum-E & 1 \\
I-A & 0.994 & P. microcladioides-E & 0.009 \\
J-A & 1 & H-G & 0.103 \\
K-A & 1 & I-G & 1 \\
P. cirrhosum-A & 0.868 & J-G & 1 \\
P. microcladioides-A & 0.151 & K-G & 0.954 \\
C-B & 1 & P. cirrhosum-G & 1 \\
E-B & 0.177 & P. microcladioides-G & 0.031 \\
G-B & 0.511 & I-H & 0.024 \\
H-B & 0.995 & J-H & 0.741 \\
I-B & 0.847 & K-H & 0.292 \\
J-B & 0.982 & P. cirrhosum-H & 0.223 \\
K-B & 0.951 & P. microcladioides $-\mathrm{H}$ & 0.841 \\
P. cirrhosum-B & 0.618 & J-I & 1 \\
P. microcladioides-B & 0.495 & K-I & 1 \\
E-C & 0.375 & P. cirrhosum-I & 0.997 \\
G-C & 0.563 & P. microcladioides-I & 0.068 \\
H-C & 1 & K-J & 1 \\
I-C & 0.833 & P. cirrhosum-J & 0.999 \\
J-C & 0.948 & P. microcladioides-J & 0.229 \\
K-C & 0.930 & P. cirrhosum-K & 0.956 \\
P. cirrhosum-C & 0.592 & P. microcladioides-K & 0.088 \\
P. microcladioides-C & 0.931 & & \\
& & &
\end{tabular}


Table A.14. Results of the Tukey Tests multiple comparison of means 95\% family-wise confidence level for NASR.

\begin{tabular}{l|c|l|c} 
Species & p-value & Species & p-value \\
\hline P. cirrhosum- & 0.002 & G-E & 0.797 \\
P. microcladioides & & & \\
B-A & 1 & H-E & 0.093 \\
C-A & 1 & I-E & 0.943 \\
E-A & 0.003 & J-E & 1 \\
G-A & 0.001 & K-E & 0.039 \\
H-A & 0.991 & P. cirrhosum-E & 0.999 \\
I-A & 0.326 & P. microcladioides-E & $<0.001$ \\
J-A & 0.730 & H-G & 0.016 \\
K-A & 0.984 & I-G & 0.291 \\
P. cirrhosum-A & 0.072 & J-G & 0.777 \\
$P$. microcladioides-A & 0.125 & K-G & 0.009 \\
C-B & 1 & P. cirrhosum-G & 1 \\
E-B & 0.018 & P. microcladioides-G & $<0.001$ \\
G-B & 0.004 & I-H & 0.912 \\
H-B & 0.994 & J-H & 0.976 \\
I-B & 0.463 & K-H & 1 \\
J-B & 0.761 & P. cirrhosum-H & 0.273 \\
K-B & 0.992 & P. microcladioides-H & 0.045 \\
P. cirrhosum-B & 0.098 & J-I & 1 \\
P. microcladioides-B & 0.204 & K-I & 0.853 \\
E-C & 0.159 & P. cirrhosum-I & 0.865 \\
G-C & 0.030 & P. microcladioides-I & 0.006 \\
H-C & 0.994 & K-J & 0.966 \\
I-C & 0.684 & P. cirrhosum-J & 0.981 \\
J-C & 0.802 & P. microcladioides-J & 0.030 \\
K-C & 0.993 & P. cirrhosum-K & 0.225 \\
$P$. cirrhosum-C & 0.184 & P. microcladioides-K & 0.036 \\
P. microcladioides-C & 0.613 & & \\
& & &
\end{tabular}


Table A.15. Results of the Tukey Tests multiple comparison of means $95 \%$ family-wise confidence level for ANRAS.

\begin{tabular}{|c|c|c|c|}
\hline Species & p-value & Species & p-value \\
\hline $\begin{array}{l}\text { P. cirrhosum- } \\
\text { P. microcladioides }\end{array}$ & 0.996 & G-E & 0.008 \\
\hline B-A & 0.92 & H-E & 1 \\
\hline C-A & 1 & I-E & 0.994 \\
\hline E-A & 1 & $J-E$ & 1 \\
\hline G-A & 0.025 & K-E & 0.131 \\
\hline $\mathrm{H}-\mathrm{A}$ & 0.952 & P. cirrhosum-E & 1 \\
\hline I-A & 1 & P. microcladioides $-\mathrm{E}$ & 0.997 \\
\hline $\mathrm{J}-\mathrm{A}$ & 1 & $\mathrm{H}-\mathrm{G}$ & 0.004 \\
\hline $\mathrm{K}-\mathrm{A}$ & 0.426 & $\mathrm{I}-\mathrm{G}$ & 0.111 \\
\hline P. cirrhosum-A & 1 & $\mathrm{~J}-\mathrm{G}$ & 0.121 \\
\hline P. microcladioides-A & 1 & K-G & 0.519 \\
\hline C-B & 1 & P. cirrhosum-G & 0.102 \\
\hline E-B & 0.998 & P. microcladioides $-\mathrm{G}$ & 0.566 \\
\hline G-B & 0.005 & $\mathrm{I}-\mathrm{H}$ & 0.906 \\
\hline H-B & 1 & $\mathrm{~J}-\mathrm{H}$ & 1 \\
\hline I-B & 0.865 & $\mathrm{~K}-\mathrm{H}$ & 0.063 \\
\hline $\mathrm{J}-\mathrm{B}$ & 1 & P. cirrhosum-H & 1 \\
\hline K-B & 0.072 & P. microcladioides $-\mathrm{H}$ & 0.966 \\
\hline P. cirrhosum-B & 1 & $\mathrm{~J}-\mathrm{I}$ & 0.999 \\
\hline P. microcladioides-B & 0.944 & K-I & 0.893 \\
\hline E-C & 1 & P. cirrhosum-I & 0.997 \\
\hline G-C & 0.102 & P. microcladioides-I & 1 \\
\hline $\mathrm{H}-\mathrm{C}$ & 1 & K-J & 0.731 \\
\hline $\mathrm{I}-\mathrm{C}$ & 0.997 & P. cirrhosum-J & 1 \\
\hline $\mathrm{J}-\mathrm{C}$ & 1 & P. microcladioides- $\mathrm{J}$ & 0.998 \\
\hline $\mathrm{K}-\mathrm{C}$ & 0.668 & P. cirrhosum-K & 0.668 \\
\hline P. cirrhosum-C & 1 & P. microcladioides $-\mathrm{K}$ & 0.999 \\
\hline P. microcladioides-C & 0.996 & & \\
\hline
\end{tabular}


Table A.16. Results of the Tukey Tests multiple comparison of means 95\% family-wise confidence level for CBR.

\begin{tabular}{l|c|l|c} 
Species & p-value & Species & \multicolumn{1}{l}{ p-value } \\
\hline P. cirrhosum- & 0.999 & G-E & 0.889 \\
P. microcladioides & & & \\
B-A & 1 & H-E & 0.067 \\
C-A & 0.980 & I-E & 0.999 \\
E-A & 0.796 & J-E & 0.999 \\
G-A & 1 & K-E & 0.931 \\
H-A & 0.737 & P. cirrhosum-E & 1 \\
I-A & 1 & P. microcladioides-E & 0.950 \\
J-A & 1 & H-G & 0.988 \\
K-A & 0.111 & I-G & 0.999 \\
P. cirrhosum-A & 1 & J-G & 1 \\
P. microcladioides-A & 1 & K-G & 0.328 \\
C-B & 0.988 & P. cirrhosum-G & 0.999 \\
E-B & 0.928 & P. microcladioides-G & 1 \\
G-B & 1 & I-H & 0.559 \\
H-B & 0.879 & J-H & 0.978 \\
I-B & 1 & K-H & 0.004 \\
J-B & 1 & P. cirrhosum-H & 0.824 \\
K-B & 0.310 & P. microcladioides-H & 1 \\
P. cirrhosum-B & 1 & J-I & 1 \\
P. microcladioides $-\mathrm{B}$ & 1 & K-I & 0.674 \\
E-C & 1 & P. cirrhosum-I & 1 \\
G-C & 0.971 & P. microcladioides-I & 0.999 \\
H-C & 0.526 & K-J & 0.876 \\
I-C & 1 & P. cirrhosum-J & 1 \\
J-C & 0.999 & P. microcladioides-J & 1 \\
K-C & 1 & P. cirrhosum-K & 0.991 \\
P. cirrhosum-C & 1 & P. microcladioides-K & 0.587 \\
P. microcladioides $-\mathrm{C}$ & 0.975 & &
\end{tabular}


Table A.17. Results of the Tukey Tests multiple comparison of means 95\% family-wise confidence level for SERBR.

\begin{tabular}{l|c|l|c} 
Species & p-value & Species & p-value \\
\hline P. cirrhosum- & 0.036 & G-E & $<0.001$ \\
P. microcladioides & & & \\
B-A & 0.970 & H-E & $<0.001$ \\
C-A & 0.999 & I-E & $<0.001$ \\
E-A & $<0.001$ & J-E & 1 \\
G-A & 0.989 & K-E & $<0.001$ \\
H-A & 0.947 & P. cirrhosum-E & 1 \\
I-A & 0.970 & P. microcladioides-E & 0.003 \\
J-A & 0.017 & H-G & 1 \\
K-A & 0.900 & I-G & 1 \\
P. cirrhosum-A & 0.017 & J-G & 0.010 \\
$P$. microcladioides-A & 0.999 & K-G & 1 \\
C-B & 1 & P. cirrhosum-G & 0.010 \\
E-B & $<0.001$ & P. microcladioides-G & 1 \\
G-B & 1 & I-H & 1 \\
H-B & 1 & J-H & 0.004 \\
I-B & 1 & K-H & 1 \\
J-B & 0.005 & P. cirrhosum-H & 0.004 \\
K-B & 1 & P. microcladioides-H & 1 \\
P. cirrhosum-B & 0.005 & J-I & 0.005 \\
$P$. microcladioides-B & 1 & K-I & 1 \\
E-C & 0.003 & P. cirrhosum-I & 0005 \\
G-C & 1 & P. microcladioides-I & 1 \\
H-C & 1 & K-J & 0.003 \\
I-C & 1 & P. cirrhosum-J & 1 \\
J-C & 0.036 & P. microcladioides-J & 0.036 \\
K-C & 1 & P. cirrhosum-K & 0.003 \\
$P$. cirrhosum-C & 0.036 & P. microcladioides-K & 1 \\
$P$. microcladioides-C & 1 & & \\
& & &
\end{tabular}

